\title{
Patient-Held Maternal and/or Child Health Records: Meeting the Information Needs of Patients and Healthcare Providers in Developing Countries?
}

\author{
Kathleen E. Turner ${ }^{1}$, Sherrilynne Fuller ${ }^{1}$ \\ ${ }^{1}$ University of Washington, Information School and \\ University of Washington, Center for Public Health Informatics
}

\begin{abstract}
Though improvements in infant and maternal mortality rates have occurred over time, women and children still die every hour from preventable causes. Various regional, social and economic factors are involved in the ability of women and children to receive adequate care and prevention services. Patient-held maternal and/or child health records have been used for a number of years in many countries to help track health risks, vaccinations and other preventative health measures performed. Though these records are primarily designed to record patient histories and healthcare information and guide healthcare workers providing care, because the records are patient-held, they also allow families a greater ability to track their own health and prevention strategies.
\end{abstract}

A literature search was performed to answer these questions: (1) What are maternal information needs regarding pregnancy, post-natal and infant healthcare, especially in developing countries? (2) What is known about maternal information seeking behavior in developing countries? (3) What is the history and current state of maternal and/or child patient-held healthcare records, do they provide for the information needs of the healthcare provider and what are the effects and outcomes of patient-held records in general and for maternal and/or child health in particular?

Specific information needs of pregnant women and mothers are rarely studied. The small numbers of maternal information behavior results available indicate that mothers, in general, prefer to receive health information directly from their healthcare provider as opposed to from other sources (written, etc.) Overall, in developing countries, patient-held maternal and/or child healthcare records have a mostly positive effect for both patient and care provider. Mothers and children with records tend to have better outcomes in healthcare and preventative measures. Further research into the information behaviors of pregnant women and mothers to determine the extent of reliance on interpersonal information seeking is recommended before expending significant resources on enhanced patient-held maternal and/or child healthcare records including storage on mobile devices. In particular, research is needed to explore the utility of providing targeted health messages to mothers regarding their own health and that of their children; this might best be accomplished through mobile technologies. 
Patient-Held Maternal and/or Child Health Records: Meeting the Information Needs of Patients and Healthcare Providers in Developing Countries?

\section{Keywords: Child Health Services, Developing Countries, Information Seeking Behavior, Maternal Health Services, Medical Records}

\section{Introduction}

Around the world in developing nations, maternal and child healthcare has been on the forefront of consciousness for improving the lives of global citizens [1-3]. Though improvements in infant and maternal mortality rates have occurred over time, women and children still die every hour from preventable causes [4-6]. In addition, each country has its own policies and challenges with delivering healthcare to its citizens [7-9]. Various regional, social and economic factors are involved in the ability of women and children to receive adequate care and prevention services $[10,11]$. Most importantly, though, is making sure the improvements in maternal and child healthcare and preventative measures in developing countries lead to decreased morbidity and mortality in these vulnerable populations [12-14]. The United Nations (UN) Millennium Development Goals for 2015 include several goals defined by the World Health Organization (WHO) as pertaining to health, particularly in developing countries. These health related goals include: worldwide reduction in maternal mortality by three-fourths and in mortality of children under the age of five by two-thirds from year 2000 levels [15]; forty percent of these childhood deaths are in newborns [16]. Only 19 of the 68 priority countries are on track to reach the healthrelated goals for child mortality and maternal health [15]. Though many of these struggling countries have been severely impacted by the HIV/AIDS epidemic [17], the major causes of neonatal death continue to be sepsis and pneumonia, birth asphyxia, complications of pre-term birth, tetanus and diarrhea $[18,19]$. The majority of these conditions could be prevented or treated with proper pre-natal, childbirth and neonatal healthcare, maternal and child nutrition and maternal education [18].

Given the lack of access to healthcare in developing countries, there have been various measures proposed and enacted to enable patients to become greater participants in their own healthcare [20]. In developing countries, self-care measures are important for empowering people and communities who have limited access to a formal healthcare system to make a difference in their own well-being [19-22]. Medical personnel have worked to improve systems for accurately determining higher risk patients, in particular pregnant women who are most likely to need referral for delivery of their babies $[4,19,21]$. Other healthcare interventions include timely vaccination, treatment for infectious and parasitic diseases and malaria, prevention of nutritional deficiencies, smoking cessation education and prophylactic therapy for HIV/AIDS [16, 18, 21]. Patient-held maternal and/or child health records (PHMR or PHCR) have been used for a number of years in many countries to help track health risks, vaccinations and other preventative health measures performed [23-27]. Though these records are designed to record patient histories and healthcare information and to guide healthcare workers providing care, because the records are patient-held, they also allow families a greater ability to track their own health and prevention strategies [7, 27]. 
Patient-Held Maternal and/or Child Health Records: Meeting the Information Needs of Patients and Healthcare Providers in Developing Countries?

\section{Objectives}

In preparation for a pilot project to transfer a patient-held mother and child health record from paper to a web-enabled cell phone platform, a literature review was needed to help answer these general questions:

1) What are maternal information needs regarding pregnancy, post-natal and infant healthcare, especially in developing countries?

2) What is known about maternal information seeking behavior in developing countries?

3) What is the history and current state of maternal and/or child patient-held healthcare records (especially in developing countries,) do they provide for the information needs of the healthcare provider and what are the effects and outcomes of patient-held records in general and for maternal and/or child health in particular?

The revised (2010) Kenyan Maternal \& Child Health Booklet provides a good example of a paper record used currently in a developing country [28-31]. This 17-page booklet is larger than many of the other maternal-child records [27], and has room for recording information regarding one pregnancy and child. Most of the seven pages of "Maternal Profile" seem designed for use by the healthcare provider; it includes the medical, surgical and obstetrical history. There are spaces for recording examination findings from first encounter to delivery. A graph for tracking the mother's weight gain, preventive therapy schedule, family planning chart, and notes section seem to be the main areas for providing for maternal information needs regarding the pregnancy. The "Child Health Card" section of the booklet seems more designed to provide information to the child's family. On almost every page, there are notes for parents such as immunization and vitamin reminders, developmental milestones, appropriate weight to height chart, retroviral prophylaxis chart and follow-up, notes, and infant feeding recommendations.

\section{Methods}

This study included two related literature searches performed concurrently. Databases searched include: CINAHL Plus, Dissertation Abstracts, EMBASE, Global Health Library, Global Health Archive, PubMed, Science Direct, Social Science Research Network, Web of Science, WHO Library Database (WHOLIS) and WHO Statistical Information System (WHOSIS). For the first query topic the Library, Information Science \& Technology Abstracts (LISTA) database was also included. Searches took place in January and February 2011; articles retrieved were limited to the English language literature. The searches were conceptual in nature. Approaching the two questions regarding maternal information seeking and information needs, the first search included the concepts of <maternal or pregnant women's healthcare/care-giving information behavior (information needs, information seeking)> and <developing countries>. The second search centered on answering the third question regarding patient-held records and their usefulness. This search utilized the idea of <patient-held maternal and/or child healthcare record>, then added in the notion of <outcomes>. The search was expanded by the use of pearlgrowing techniques [32]; applying database-specific subject headings or descriptors from a known article to search for related articles [33]. Investigating database-identified related articles, article citations and article reference lists further expanded the search. 
Some general search terms were used either combined or separately for each topic. The search terms listed are in a single format, but the format was altered depending on the search criteria and preferential use by each individual database. Search strings were also expanded and contracted depending on the number of results obtained in each individual database, and search terms might include: ("mother" OR "maternal"), ("child"), ("health" OR "medical"), ("information" OR "data"), and ("developing" OR "undeveloped" OR "third world"). To further define the searches, the following terms were added: ("information need"” OR "information seek*" OR "information behavior"), ("record" OR "card" OR "booklet"), ("health information system"), ("patient held" OR "hand held") and ("outcomes"). Articles focusing on behavior of information seeking in specific places, such as the Internet or libraries, were not included. Pearlgrowing techniques were especially important for the maternal and child record search. In particular, use of the subject headings and reference list for the 1993, multi-site study, Evaluation of the home-based maternal record: a WHO collaborative [24], proved particularly helpful for locating literature on this topic.

\section{Results}

\section{A. Maternal Information Needs and Information Seeking Behavior}

The literature covering maternal information behavior specifically for medical or health related information needs in developing countries seems rather limited. Only eight published papers from six separate studies of information behavior, including health information needs, of women and mothers in developing countries were retrieved using the literature search criteria (Table 1). Health information needs for family, prenatal and infant care are ranked high in the studies of overall women's information needs in developing countries [34, 35, 38, 39], and a few studies look specifically at health information seeking behavior in these populations [36, 37, 40, 41]. A few common themes emerge from the available research literature; mothers in the developing countries studied tend to seek medical information and advice for their children and families more commonly than searching for other information needs, and the first source or most common source for information comes from other people. Basic infant and child developmental and care information are mentioned as important to mothers in the studies from Tanzania and Turkey $[36,37,40]$.

In order to get a broader view of maternal information behavior, some studies of disadvantaged mothers from developed countries were also included ( $\underline{\text { Table 2 }}$. . While these studies come from different countries and regions of the world, they show some interesting similarities as well as trends in the direction of information behavior. Unfortunately, due to the small number of studies and the small number of participants, true generalities cannot be drawn, though comparisons may be possible. The earlier studies from the 1990s in developing countries [34, 35] show women using personal information sources first when seeking information for many reasons including health related. The later studies, and studies from developed countries [36-40, 42-47], indicate that women, both in developed and developing countries, seek a majority of health-related information from their healthcare providers. The one study of adolescents, girls and boys, shows a majority of these young people from sub-Saharan Africa use mass media sources in addition to school and personal sources to meet their reproductive and sexual health needs [41]. The theme that comes through all of these studies is the idea that pregnant women and mothers from all 
different societies, both developing and developed, show a preference for receiving health information from a person, whether a healthcare provider or not. Mothers in the population of adolescents in sub-Saharan Africa [41] appear to be the main exception to that finding.

\section{B. Maternal and/or Child Healthcare Record}

\section{1) Healthcare Providers Information Needs}

The articles listed in Table $\mathbf{3}$ are, for the most part, descriptions of various forms of the maternal and/or child healthcare record, and describe the specific information needs of maternal and/or child healthcare providers as they offer suggestions for the data set and format important to collect to provide appropriate prenatal and early childhood care. It seems clear that development proceeded over a number of years to arrive at the most current versions of the maternal and child record in developing countries [27, 31]. Currently these records are individualized for each country or region, but include information such as: the names of the mother, father and child; the child's date of birth; antenatal examination findings; recommended vaccination and prophylactic therapy schedule for the mother and child; growth charts for both the child and pregnant woman; varying levels of advice for care during pregnancy and young childhood; as well as location specific physical parameters and findings such as maternal blood pressure, maternal hemoglobin and child's developmental and nutritional status. 
Table 1. Health information needs studies (concerning mothers, women/families and/or reproductive health) in developing countries

\begin{tabular}{|c|c|c|c|}
\hline Study & $\begin{array}{l}\text { Type of study } \\
\text { (Number of } \\
\text { participants) }\end{array}$ & Research question* & Results * \\
\hline [34] Fairer-Wessels FA. 1990. & $\begin{array}{l}\text { Qualitative } \\
\text { survey and } \\
\text { interview } \\
(\# 80)\end{array}$ & $\begin{array}{l}\text { What are the daily } \\
\text { information needs of } \\
\text { urban black South } \\
\text { African women, are } \\
\text { they generally able to } \\
\text { fulfill those needs, } \\
\text { how and where do } \\
\text { they search and } \\
\text { would development } \\
\text { of Community } \\
\text { Information Centers } \\
\text { help? }\end{array}$ & $\begin{array}{l}\text { Generally these women use } \\
\text { interpersonal sources for } \\
\text { seeking information needs, and } \\
\text { the most commonly sought } \\
\text { information is regarding health } \\
\text { issues. A community } \\
\text { information center sounds like a } \\
\text { good idea (no reasons really } \\
\text { offered). }\end{array}$ \\
\hline [35] Ngimwa, P, et al. 1997. & $\begin{array}{l}\text { Qualitative } \\
\text { survey and } \\
\text { interview } \\
(\# 312)\end{array}$ & $\begin{array}{l}\text { What is the media } \\
\text { accessibility and use } \\
\text { of rural women in } \\
\text { Kenya? Additionally } \\
\text { what are their main } \\
\text { information needs } \\
\text { and information } \\
\text { sources? }\end{array}$ & $\begin{array}{l}\text { The women in this study tend to } \\
\text { use interpersonal sources of } \\
\text { information most frequently } \\
\text { (60\% use friends and relatives, } \\
\text { and } 34 \% \text { use professionals as a } \\
\text { first information source, with } \\
74.1 \% \text { expressing satisfaction } \\
\text { with source) and the researchers } \\
\text { recommend alternative methods } \\
\text { for providing information to } \\
\text { these women rather than media } \\
\text { like radio. Women tend to have } \\
\text { most questions about healthcare } \\
\text { needs (43.3\%) and } \\
\text { farming/agricultural issues } \\
(29.8 \%) \text {. }\end{array}$ \\
\hline [36] Lugina HI, et al. 2001. & $\begin{array}{l}\text { Qualitative } \\
\text { survey } \\
\text { interview } \\
(\# 110) \\
\text { Qualitative } \\
\text { interview + } \\
\text { card sorting } \\
\text { activity (\#110) }\end{array}$ & $\begin{array}{l}\text { What are the } \\
\text { concerns of first time } \\
\text { mothers in Dar Es } \\
\text { Salaam, Tanzania } \\
\text { immediately and six } \\
\text { weeks post-partum? }\end{array}$ & $\begin{array}{l}\text { In this population, some } \\
\text { maternal worries change over } \\
\text { six weeks, some stay the same. } \\
\text { Worries were mainly around the } \\
\text { baby's general condition (with } \\
\text { lesser concern about care and } \\
\text { behavior) and the mothers' } \\
\text { feelings (with lesser concerns } \\
\text { regarding appearance, family } \\
\text { reactions, and sexuality), } \\
\text { switching to more interests and } \\
\text { confidences in these areas after } 6 \\
\text { weeks. Questions are raised } \\
\text { about how to provide timely }\end{array}$ \\
\hline
\end{tabular}




\begin{tabular}{|c|c|c|c|}
\hline & & $\begin{array}{l}\text { information in } \\
\text { developing } \\
\text { countries? }\end{array}$ & $\begin{array}{l}\text { information. Overall between 1- } \\
6 \text { weeks post partum, worries } \\
\text { decrease from } 29 \%-15 \% \text { (about } \\
\text { baby from } 31 \%-14 \% \text { \& self } \\
\text { from } 30 \%-20 \% \text { ) and interests } \\
\text { (overall } 38 \%-42 \% \text {, baby } 41 \%- \\
50 \% \text {, self } 38 \%-41 \% \text { ), and } \\
\text { confidences (overall 32\%-43\%, } \\
\text { baby } 29 \%-36 \% \text {, self } 32 \%-39 \% \text { ) } \\
\text { increase. This study will help } \\
\text { healthcare providers to } \\
\text { understand the types of } \\
\text { information these women are } \\
\text { looking for post-partum. } \\
\text { Additionally, using card sorting } \\
\text { seems to get better response than } \\
\text { just interview alone for } \\
\text { concerns, interests, etc. of first } \\
\text { time mothers. }\end{array}$ \\
\hline $\begin{array}{l}\text { [38] Mooko, N. P. } 2005 . \\
\text { [39] Mooko, N. P. } 2002 .\end{array}$ & $\begin{array}{l}\text { Qualitative } \\
\text { interview and } \\
\text { focus groups } \\
(\# 60)\end{array}$ & $\begin{array}{l}\text { What are the } \\
\text { information needs } \\
\text { and information } \\
\text { seeking behaviors of } \\
\text { rural Botswanan } \\
\text { women? }\end{array}$ & $\begin{array}{l}\text { The most common information } \\
\text { need of women in the study } \\
\text { related to health information for } \\
\text { the women and their families, } \\
\text { and the most common and } \\
\text { helpful information source was a } \\
\text { healthcare provider. }\end{array}$ \\
\hline [40] Ertem IO, et al. 2007. & $\begin{array}{l}\text { Random } \\
\text { survey and } \\
\text { interviews } \\
(\# 1200)\end{array}$ & $\begin{array}{l}\text { What do mothers in a } \\
\text { developing country } \\
\text { (Turkey) know about } \\
\text { young child } \\
\text { development? }\end{array}$ & $\begin{array}{l}\text { In general, mothers felt that } \\
\text { developmental milestones occur } \\
\text { later than actual for normal } \\
\text { children- the majority of women } \\
\text { did not know that sight ( } 52 \%) \text {, } \\
\text { vocalization }(79 \%) \text {, social } \\
\text { smiling ( } 59 \%) \text {, and overall brain } \\
\text { development ( } 68 \% \text { ) begin in the } \\
\text { early months of life. Women } \\
\text { with more education and fewer } \\
\text { children had a better idea of } \\
\text { actual childhood development. } \\
\text { This study suggests that } \\
\text { healthcare providers need to } \\
\text { educate mothers in child } \\
\text { development for optimum } \\
\text { provision of pediatric healthcare. }\end{array}$ \\
\hline [41] Bankole A, et al. 2007. & $\begin{array}{l}\text { National } \\
\text { household } \\
\text { survey }\end{array}$ & $\begin{array}{l}\text { What is the } \\
\text { knowledge level of } \\
\text { young teens in four } \\
\text { sub-Saharan } \\
\text { countries (Burkina } \\
\text { Faso, Malawi, } \\
\text { Uganda, and Ghana), }\end{array}$ & $\begin{array}{l}\text { These kids use multiple } \\
\text { information sources, most } \\
\text { commonly mass media ( } 45.6 \%- \\
78.9 \% \text { depending on gender and } \\
\text { country), but also teacher/school } \\
(17.7 \%-69.8 \%, \text { depending on } \\
\text { gender and country) and friends }\end{array}$ \\
\hline
\end{tabular}


Patient-Held Maternal and/or Child Health Records: Meeting the Information Needs of Patients and Healthcare Providers in Developing Countries?

\begin{tabular}{|l|l|l|l|}
\hline & & $\begin{array}{l}\text { and how do they fill } \\
\text { their information } \\
\text { needs regarding } \\
\text { sexual behavior, STIs } \\
\text { and pregnancy? }\end{array}$ & $\begin{array}{l}\text { gender and country). The } \\
\text { researchers suggest that in- } \\
\text { school education programs } \\
\text { might be most effective. }\end{array}$ \\
\hline
\end{tabular}

* See notes regarding research question(s) and results

Table 2. Health information needs studies of mothers (particularly disadvantaged mothers) in developed countries

\begin{tabular}{|c|c|c|c|}
\hline Study & $\begin{array}{l}\text { Type of study } \\
\text { (Number of } \\
\text { participants) }\end{array}$ & Research question* & Results* \\
\hline [42] Green JM, et al. 1990. & $\begin{array}{l}\text { Prospective } \\
\text { survey }(\# 825)\end{array}$ & $\begin{array}{l}\text { How do expectations of } \\
\text { childbirth coincide with } \\
\text { satisfaction, especially } \\
\text { in the realm of feelings } \\
\text { of control and adequate } \\
\text { information reception } \\
\text { on the part of the } \\
\text { mother (southeastern } \\
\text { England)? }\end{array}$ & $\begin{array}{l}\text { In this study, high expectations } \\
\text { did not seem to lead to poor } \\
\text { outcomes, and lower expectations } \\
\text { seemed to lead to less } \\
\text { satisfaction. Women wanted to } \\
\text { retain control as much as possible } \\
\text { and many reported that greater } \\
\text { information given to them by } \\
\text { their healthcare providers about } \\
\text { what to expect led to a greater } \\
\text { feeling of control. }\end{array}$ \\
\hline [43] Baker LM, et al. 2007. & $\begin{array}{l}\text { Qualitative } \\
\text { interviews } \\
(\# 30)\end{array}$ & $\begin{array}{l}\text { What are the health } \\
\text { literacy levels, and } \\
\text { information seeking } \\
\text { behaviors toward the } \\
\text { vaccines given to their } \\
\text { children of this group } \\
\text { of mothers? }\end{array}$ & $\begin{array}{l}\text { In this very small sample, most of } \\
\text { the women were unaware of the } \\
\text { purpose of the vaccines their } \\
\text { children were receiving ( } 26 \text { of } \\
30 \text { ). Health literacy levels of this } \\
\text { group of Detroit mothers were } \\
\text { relatively low, and they tended to } \\
\text { receive their information } \\
\text { regarding their children's } \\
\text { vaccines from the healthcare } \\
\text { provider ( } 22 \% \text { from doctors, } \\
18 \% \text { from clinic nurses, the rest } \\
\text { from } 1-9 \% \text { from } 10 \text { other } \\
\text { sources). }\end{array}$ \\
\hline [44] Smith SK, et al. 2009. & $\begin{array}{l}\text { Qualitative } \\
\text { interviews } \\
(\# 73)\end{array}$ & $\begin{array}{l}\text { How do education } \\
\text { levels and health } \\
\text { literacy affect people's } \\
\text { information needs and } \\
\text { expectations for health } \\
\text { decision-making? }\end{array}$ & $\begin{array}{l}\text { In this population from Sydney, } \\
\text { Australia, more highly } \\
\text { educated/health literate patients } \\
\text { seem to take a higher } \\
\text { responsibility for making their } \\
\text { own decisions regarding health } \\
\text { care, whereas less educated } \\
\text { patients relied more on health } \\
\text { care providers to make decisions } \\
\text { to which they would either agree }\end{array}$ \\
\hline
\end{tabular}


Patient-Held Maternal and/or Child Health Records: Meeting the Information Needs of Patients and Healthcare Providers in Developing Countries?

\begin{tabular}{|c|c|c|c|}
\hline & & & or disagree. \\
\hline [45] Shieh C, et al. 2009. & $\begin{array}{l}\text { Standardized } \\
\text { test of health } \\
\text { literacy and } \\
\text { interview } \\
\text { (\#143) }\end{array}$ & $\begin{array}{l}\text { How do health literacy } \\
\text { levels relate to the use } \\
\text { of health information } \\
\text { sources and barriers to } \\
\text { information seeking in } \\
\text { low-income pregnant } \\
\text { women in urban } \\
\text { Midwestern U.S.? }\end{array}$ & $\begin{array}{l}\text { Higher levels of health literacy } \\
\text { were related to a greater ability to } \\
\text { use multiple information sources } \\
\text { with lower barriers to information } \\
\text { seeking. Results suggest that } \\
\text { information seeking skills should } \\
\text { be taught to patients with lower } \\
\text { health literacy. Both the high } \\
(85.3 \%) \text { and low health literacy } \\
(14.7 \%) \text { group used healthcare } \\
\text { professionals most frequently } \\
\text { (low } 90.5 \% \text {, high } 74.6 \%) \text {, with } \\
\text { books/brochures (low } 57.1 \% \text {, } \\
\text { high } 58.2 \%) \text { and family and } \\
\text { friends next most frequently (low } \\
57.1 \%, \text { high } 51.5 \%) \text {. }\end{array}$ \\
\hline [46] Shieh C, et al. 2009. & $\begin{array}{l}\text { Qualitative } \\
\text { interviews } \\
(\# 84)\end{array}$ & $\begin{array}{l}\text { What are the } \\
\text { information seeking } \\
\text { behaviors (information } \\
\text { needs and barriers) in } \\
\text { this population of low- } \\
\text { income pregnant } \\
\text { women? }\end{array}$ & $\begin{array}{l}\text { In this urban Midwestern U.S. } \\
\text { population it was shown that } \\
\text { information seeking was highest } \\
\text { in those women with the highest } \\
\text { needs (asthma and first } \\
\text { pregnancy) and the lowest } \\
\text { barriers to obtaining information. } \\
\text { Also showed that healthcare } \\
\text { providers were the highest } \\
\text { source of information. }\end{array}$ \\
\hline [47] Shieh C, et al. 2010. & $\begin{array}{l}\text { Survey and } \\
\text { standardized } \\
\text { testing (\#143) }\end{array}$ & $\begin{array}{l}\text { Do health literacy, } \\
\text { positive measures of } \\
\text { mother's fetal locus of } \\
\text { control and maternal } \\
\text { self-efficacy correlate } \\
\text { positively with health } \\
\text { information seeking in } \\
\text { this Midwestern U.S. } \\
\text { population of low- } \\
\text { income pregnant } \\
\text { women? }\end{array}$ & $\begin{array}{l}\text { Feelings of maternal control } \\
\text { toward fetal wellbeing ( } \mathrm{r}=0.27, \\
\mathrm{p}=0.003 \text { ) and self-efficacy } \\
(\mathrm{r}=0.33, \mathrm{p}=0.0004) \text { were } \\
\text { positively correlated with } \\
\text { maternal information seeking. } \\
\text { Health literacy was not ( } \mathrm{r}=-0.05 \text {, } \\
\mathrm{p}=0.63 \text { ). In this study, low health } \\
\text { literacy was correlated with a } \\
\text { feeling of lowering self-fetus } \\
\text { control, in other words, these } \\
\text { pregnant women tended to rely on } \\
\text { information from healthcare } \\
\text { providers more than women with } \\
\text { higher health literacy. }\end{array}$ \\
\hline
\end{tabular}

* See notes regarding research question(s) and results 
Patient-Held Maternal and/or Child Health Records: Meeting the Information Needs of Patients and Healthcare Providers in Developing Countries?

Table 3. Maternal and/or child healthcare record information needs of providers

\begin{tabular}{|c|c|c|c|}
\hline Study & $\begin{array}{l}\text { Type of } \\
\text { study/document }\end{array}$ & Research question* & Results* \\
\hline \multicolumn{4}{|l|}{ Studies of Patient-Held Records } \\
\hline [48] Hartfield VJ. 1973. & Descriptive & $\begin{array}{l}\text { Is there a better } \\
\text { method of record } \\
\text { keeping for mothers } \\
\text { in developing } \\
\text { countries? }\end{array}$ & $\begin{array}{l}\text { This is an early } \\
\text { proposal for use of } \\
\text { card to improve } \\
\text { record keeping. } \\
\text { Positive outcomes } \\
\text { for PHMR } \\
\text { suggested. }\end{array}$ \\
\hline [49] Dissevelt AG, et al. 1976. & Descriptive & $\begin{array}{l}\text { What are features of } \\
\text { record to facilitate } \\
\text { detection of high- } \\
\text { risk pregnancy in } \\
\text { rural Kenya? }\end{array}$ & $\begin{array}{l}\text { Earlier Kenyan } \\
\text { maternal card, } \\
\text { positive benefits } \\
\text { suggested. }\end{array}$ \\
\hline [50] Sims P. 1978. & Descriptive & $\begin{array}{l}\text { What are features of } \\
\text { record to facilitate } \\
\text { detection of high- } \\
\text { risk pregnancy? }\end{array}$ & $\begin{array}{l}\text { Provider } \\
\text { information, dense } \\
\text { information, not for } \\
\text { illiterates, PH card } \\
\text { prototype. Positive } \\
\text { value felt by author, } \\
\text { especially since } \\
\text { patient generally has } \\
\text { information } \\
\text { available- important } \\
\text { especially in case of } \\
\text { emergency }\end{array}$ \\
\hline [51] Shah KP, et al. 1981. & Descriptive & $\begin{array}{l}\text { What are features of } \\
\text { Indian record to } \\
\text { facilitate detection } \\
\text { of high-risk } \\
\text { pregnancy? }\end{array}$ & $\begin{array}{l}\text { Description of card, } \\
\text { apparently useful to } \\
\text { help detect risk } \\
\text { factors. }\end{array}$ \\
\hline [52] Chabot HT, et al. 1986. & Descriptive & $\begin{array}{l}\text { What are features of } \\
\text { record to facilitate } \\
\text { detection of high- } \\
\text { risk pregnancy? }\end{array}$ & $\begin{array}{l}\text { Prototype for } \\
\text { pictorial card, } \\
\text { describing the need } \\
\text { for testing and use in } \\
\text { Guinea Bissau where } \\
\text { most pre-natal care } \\
\text { done by Illiterate } \\
\text { TBAs. Results } \\
\text { unknown. Felt to be } \\
\text { necessary and } \\
\text { helpful for helping } \\
\text { TBAs, but difficult } \\
\text { to get right. } \\
\text { Suggestions for } \\
\text { single card usable for }\end{array}$ \\
\hline
\end{tabular}




\begin{tabular}{|c|c|c|c|}
\hline & & & $\begin{array}{l}\text { both lit and ill to } \\
\text { allow mother to carry } \\
\text { only one card. Area } \\
\text { determines different } \\
\text { procedures done by } \\
\text { each. }\end{array}$ \\
\hline [23] Kumar V, et al. 1988. & Descriptive & $\begin{array}{l}\text { What are features of } \\
\text { record to facilitate } \\
\text { detection of high- } \\
\text { risk } \\
\text { pregnancy/improve } \\
\text { quality of care in } \\
\text { India? }\end{array}$ & $\begin{array}{l}\text { Description of card, } \\
\text { apparently useful to } \\
\text { help detect risk } \\
\text { factors. Benefits of } \\
\text { using for illiterate } \\
\text { traditional birth } \\
\text { attendant (TBA) in } \\
\text { order to aid in earlier } \\
\text { detection of risks and } \\
\text { improved maternal } \\
\text { self-care. }\end{array}$ \\
\hline [25] World Health Organization. 1992. & $\begin{array}{l}\text { Instructional } \\
\text { booklet }\end{array}$ & $\begin{array}{l}\text { What are guidelines } \\
\text { for implementing } \\
\text { home-based child } \\
\text { health records? }\end{array}$ & $\begin{array}{l}\text { In depth instructions } \\
\text { for implementing } \\
\text { PHCR card or } \\
\text { booklet. } \\
\text { Specifications for } \\
\text { how to implement } \\
\text { and how to alter to } \\
\text { fit the particular } \\
\text { circumstances for } \\
\text { each area of } \\
\text { implementation. }\end{array}$ \\
\hline [26] World Health Organization. 1994. & $\begin{array}{l}\text { Instructional } \\
\text { book }\end{array}$ & $\begin{array}{l}\text { What are guidelines } \\
\text { for implementing } \\
\text { home-based } \\
\text { maternal records? }\end{array}$ & $\begin{array}{l}\text { In depth instructions } \\
\text { for implementing } \\
\text { PHMR card or } \\
\text { booklet. } \\
\text { Specifications for } \\
\text { how to implement } \\
\text { and how to alter to } \\
\text { fit the particular } \\
\text { circumstances for } \\
\text { each area of } \\
\text { implementation. }\end{array}$ \\
\hline
\end{tabular}

\section{Studies of Clinic-Held Records}

\begin{tabular}{|l|l|l|l|}
\hline [53] Poulton EM. 1966. & Descriptive & $\begin{array}{l}\text { Reasons for record } \\
\text { keeping for maternal } \\
\text { child health care in } \\
\text { developing } \\
\text { countries. }\end{array}$ & $\begin{array}{l}\text { Basic outline of the } \\
\text { purpose of records. }\end{array}$ \\
\hline [54] Essex BJ, et al. 1977. & Descriptive & $\begin{array}{l}\text { What are features of } \\
\text { record to facilitate } \\
\text { detection of high- } \\
\text { risk pregnancy? }\end{array}$ & $\begin{array}{l}\text { Early card for } \\
\text { providers' use, not } \\
\text { for illiterates, card } \\
\text { prototype reminder } \\
\text { of need to test }\end{array}$ \\
\hline
\end{tabular}




\begin{tabular}{|c|c|c|c|}
\hline & & & $\begin{array}{l}\text { against existing. The } \\
\text { new card } \\
\text { demonstrated a high } \\
\text { rate of agreement } \\
\text { between providers, } \\
\text { and was felt to be } \\
\text { useful in Tanzania }\end{array}$ \\
\hline [55] Alisjahbana A, et al. 1984. & $\begin{array}{l}\text { Observation } \\
(\# 20)\end{array}$ & $\begin{array}{l}\text { How can we } \\
\text { improve traditional } \\
\text { birth attendants' } \\
\text { (TBA) reporting of } \\
\text { high-risk births in } \\
\text { Indonesia? }\end{array}$ & $\begin{array}{l}\text { This study showed } \\
\text { that TBAs able to } \\
\text { report, assess, and } \\
\text { respond accurately if } \\
\text { trained and risk } \\
\text { indicators defined in } \\
\text { a way they } \\
\text { understood. }\end{array}$ \\
\hline [56] Kennedy I, et al. 1984. & Descriptive & $\begin{array}{l}\text { What are the reasons } \\
\text { for restructuring } \\
\text { record in Botswana? }\end{array}$ & $\begin{array}{l}\text { Ability to follow } \\
\text { pregnancy by use of } \\
\text { an obvious graph to } \\
\text { compare between } \\
\text { visits seems helpful } \\
\text { to catch problems. } \\
\text { Not necessarily } \\
\text { designed for } \\
\text { developing countries }\end{array}$ \\
\hline
\end{tabular}

\section{Studies of Electronic Records}

\begin{tabular}{|l|l|l|l|}
\hline [57] Moidu K, et al. 1992. & $\begin{array}{l}\text { Expert } \\
\text { consensus }\end{array}$ & $\begin{array}{l}\text { What is the essential } \\
\text { data set of an } \\
\text { electronic maternal } \\
\text { health record? }\end{array}$ & $\begin{array}{l}\text { Examines feasibility } \\
\text { of creating and using } \\
\text { the data set, data set } \\
\text { listed. Importance is } \\
\text { that data set might be } \\
\text { different for each } \\
\text { location. Data sets } \\
\text { being tested in } \\
\text { Sweden and India. }\end{array}$ \\
\hline [58] Phelan ST. 2008. & Descriptive & $\begin{array}{l}\text { What are the } \\
\text { comparisons } \\
\text { between the current } \\
\text { well-organized and } \\
\text { useful paper record } \\
\text { to an electronic } \\
\text { record (U.S.)? }\end{array}$ & $\begin{array}{l}\text { The authors clearly } \\
\text { don't want to lose the } \\
\text { positive aspects of } \\
\text { the pre-natal record } \\
\text { that has been } \\
\text { working well for a } \\
\text { number of years, but } \\
\text { recognize the } \\
\text { portability and } \\
\text { potential for back-up } \\
\text { and legibility of the } \\
\text { electronic record, } \\
\text { while recognizing } \\
\text { the inherent } \\
\text { difficulties of setting } \\
\text { up a new system. }\end{array}$ \\
\hline
\end{tabular}




\section{2) Patient Held Records}

For a number of years, a variety of developed and developing countries have used patient-held maternal health records and/or parent-held child health records [25, 26, 48-52, 59]. More recently, as described above for Kenya [31], countries have started adopting patient-held combined maternal and child health records. These records are frequently designed with guidance from the WHO, though each jurisdiction is encouraged to develop the record best suited to its culture and populace [25, 26].

The literature review results fall into a few categories based on whether utility of the record to the patient/parent (Tables 4, 5 and $\mathbf{6}$ ) or the healthcare provider (Tables 7, 8 and 9) was the main focus of the study; also whether the record was specific for maternal and/or child healthcare or for other types of healthcare. Additionally, findings tended to vary for studies carried out in developed versus developing countries.

\section{a) Utility to Patients}

The majority of results are neutral for the effects of the patient-held maternal and/or child record in the studies conducted in developing countries (Table 4). Increasing patient education was felt to be one way to improve the card's utility in all four of the studies with neutral results [59, 61-63], and use and understanding of the card is felt to be key in the two positive outcomes $[59,60]$. Where noted, loss of the record was not felt to be a significant issue $[59,63]$.

In the 13 studies showing a positive outcome for the patient-held maternal and/or child record studies in developed countries [64-76], words like confidence, control, access (better informed), satisfaction, and communication (interaction) were repeated (Table 5). In addition, in eight of the nine studies where recorded, there were few or no missing or lost records, and some families retained the records for many years [65-70, 72, 75, 77]. The two studies showing inconclusive or neutral results were focused on the health outcomes of the record $[76,77]$.

All eleven studies of the patient-held (not maternal and/or child) records were carried out in developed countries (Table 6). Results in these studies were variable. The six positive outcomes were qualitative assessments of patient benefit [78-83]. One of the two studies with negative results reports less satisfied patients, and the other reports a potential imbalance of power relationship [81, 82]. The seven studies including neutral results, were just that, the results were inconclusive [82-88]. Where noted, patients are generally willing and able to carry the card [80].

\section{b) Utility to Care Providers}

The care provider is most likely to be influenced by the results in the 15 studies of the patient-held maternal and/or child records in developing countries (Table 7). The ten positive results demonstrated here are, for the most part, improved outcomes in healthcare results or 
preventative measures such as detection of risk, quality of care, higher rates of care, as well as increased educational opportunities [24, 63, 89-96]. The six studies with neutral results can show no conclusive positive results, but provide a positive overall feeling toward the record $[61,96-100]$. In studies where noted, the majority of women were able to keep track of the record even if they weren't always brought to healthcare provider visits [63, 92, 94, 96].

The seven studies of patient-held maternal and/or child records from developed countries (Table 8) show results that most likely to influence care providers. These outcomes offer a more mixed view of the effects of the records. Definite positive benefits were shown with children's immunizations [69, 101], return of record following education about its importance [103], and impressions of improvement in communication, access and care [68, 102]. Neutral results center on management of the record $[69,103]$ and inconclusive health results [76]. Negative results arise from confidentiality concerns, increase in burden of work, size of the record, and increased surgical intervention $[68,76,104]$. This final concern noting increased surgical interventions with possession of the patient-held record might be considered positive in developing countries where detection of risk factors and elucidating the need for referral are crucial to the records' function [89-92]. The majority of patients were able to produce records when requested in studies reporting this factor $[68,69,103]$.

The three final studies (Table 9) of the influence on care providers of the patient-held (not maternal and/or child) records show some positive benefits in compliance in patients with possession of the record [81], though the other two studies demonstrate the patients just not using or carrying the record $[105,106]$.

The studies listed in Tables 4-9 delve into the usefulness of and outcomes for the patient-held record. In total, 48 studies were listed in the six categories of type of patient-held record: (maternal and/or child or not,) care provider or patient most influenced/effected, and research done in developed or developing country. Nine (one study in two categories) of the studies are felt to have mixed results [59, 68, 69, 76 (twice), 81-83, 96, 103], and six of the studies are felt to concern both patient and care provider $[61,63,68,69,76,81]$. Of these results, 37 show positive effects or influences, 24 show neutral effects or influences, while only five studies show negative effects or influences produced with use of a patient-held health care record. 
Table 4. Who studied: what studied - where

Patient: Patient held maternal and/or child records - developing countries

\begin{tabular}{|c|c|c|c|c|c|}
\hline & Type of study & Research question* & $\begin{array}{l}\text { Results } \\
\text { (positive } \\
\text { outcome of } \\
\text { having } \\
\text { record) } \\
\end{array}$ & $\begin{array}{l}\text { Results } \\
\text { (neutral) }\end{array}$ & $\begin{array}{l}\text { Results } \\
\text { (negative } \\
\text { outcome of } \\
\text { having } \\
\text { record) } \\
\end{array}$ \\
\hline [60] Kusumayati, A, 2007. & $\begin{array}{l}\text { Repeated cross-sectional survey (\#611, } \\
\# 621, \# 630 \text { ) }\end{array}$ & $\begin{array}{l}\text { What are the effects } \\
\text { of the MCH in } \\
\text { Western Sumatra on } \\
\text { using maternal } \\
\text { health services? }\end{array}$ & $\begin{array}{l}\text { The mothers } \\
\text { using (not } \\
\text { simply } \\
\text { owning) the } \\
\text { MCH had } 2.5 \\
\text { times better } \\
\text { knowledge of } \\
\text { the benefits of } \\
\text { some pre-natal } \\
\text { care measures, } \\
\text { and were } 3 \\
\text { times more } \\
\text { likely to seek } \\
\text { out needed } \\
\text { care. }\end{array}$ & & \\
\hline [59] Nakamura Y 2010. & Descriptive & $\begin{array}{l}\text { What is the history } \\
\text { of the MCH } \\
\text { Handbook in Japan? }\end{array}$ & $\begin{array}{l}\text { This study } \\
\text { included here, } \\
\text { as the MCH } \\
\text { Handbook } \\
\text { was first } \\
\text { distributed in } \\
\text { Japan in } 1947 . \\
\text { The positive } \\
\text { benefits of the } \\
\text { MCH } \\
\text { Handbook } \\
\text { include ease } \\
\text { of }\end{array}$ & $\begin{array}{l}\text { The main } \\
\text { concerns are } \\
\text { the costs } \\
\text { (though less } \\
\text { than multiple } \\
\text { separate } \\
\text { cards), the fear } \\
\text { of loss (not } \\
\text { found to be a } \\
\text { significant } \\
\text { problem), and } \\
\text { the uneven use } \\
\text { of the cards }\end{array}$ & \\
\hline
\end{tabular}


Patient-Held Maternal and/or Child Health Records: Meeting the Information Needs of Patients and Healthcare Providers in Developing Countries?

\begin{tabular}{|c|c|c|c|c|}
\hline & & & $\begin{array}{l}\text { understanding, } \\
\text { access to child } \\
\text { and maternal } \\
\text { health } \\
\text { information, } \\
\text { and having } \\
\text { records } \\
\text { available } \\
\text { when needed. }\end{array}$ & $\begin{array}{l}\text { depending on } \\
\text { the } \\
\text { quality/amount } \\
\text { of care } \\
\text { available. }\end{array}$ \\
\hline $\begin{array}{l}\text { [61] Harrison D, et al. } \\
1998 .\end{array}$ & Descriptive / interview (\#185) & $\begin{array}{l}\text { What are the } \\
\text { opinions of } \\
\text { mothers/caregivers } \\
\text { (\#150) and health } \\
\text { care providers (\#35) } \\
\text { regarding accuracy } \\
\text { and completeness of } \\
\text { the Road to Health } \\
\text { card in Cape Town, } \\
\text { South Africa? }\end{array}$ & & $\begin{array}{l}\text { Health care } \\
\text { providers like } \\
\text { the concept, } \\
\text { but would like } \\
\text { information to } \\
\text { be in a more } \\
\text { useful format. } \\
\text { Points out } \\
\text { need to } \\
\text { determine } \\
\text { what } \\
\text { information is } \\
\text { important to } \\
\text { family and } \\
\text { healthcare } \\
\text { providers in } \\
\text { order for them } \\
\text { to actually fill } \\
\text { out all } \\
\text { information. }\end{array}$ \\
\hline $\begin{array}{l}\text { [62] Mahomed K, et al. } \\
2000 .\end{array}$ & Descriptive /interview (\#51) & $\begin{array}{l}\text { How feasible is } \\
\text { having a PHMR in } \\
\text { rural Zimbabwe, and } \\
\text { do mothers } \\
\text { understand the } \\
\text { reasons for the } \\
\text { record? }\end{array}$ & & $\begin{array}{l}\text { The } \\
\text { introduction of } \\
\text { the record } \\
\text { seems feasible, } \\
\text { but much more } \\
\text { education of } \\
\text { mothers is }\end{array}$ \\
\hline
\end{tabular}


Patient-Held Maternal and/or Child Health Records: Meeting the Information Needs of Patients and Healthcare Providers in Developing Countries?

\begin{tabular}{|c|c|c|c|}
\hline & & & $\begin{array}{l}\text { needed for } \\
\text { them to } \\
\text { understand } \\
\text { value as only } \\
49.1 \% \\
\text { returned at end } \\
\text { of study. }\end{array}$ \\
\hline $\begin{array}{l}\text { [63] Tarwa, C., et al. } \\
2007 .\end{array}$ & Survey (\#300) & $\begin{array}{l}\text { Is the South African } \\
\text { Road-to-Health card } \\
\text { brought to } \\
\text { consultations and } \\
\text { used by health care } \\
\text { providers? }\end{array}$ & $\begin{array}{l}\text { The RTH card } \\
\text { is not brought } \\
\text { to } 48 \% \text { of } \\
\text { consultations. } \\
\text { Adults mostly } \\
\text { ( } 72 \% \text { ) thought } \\
\text { they were only } \\
\text { to bring the } \\
\text { card to well- } \\
\text { baby clinics. } \\
\text { Care providers } \\
\text { are missing an } \\
\text { opportunity to } \\
\text { educate and } \\
\text { provide health } \\
\text { monitoring. }\end{array}$ \\
\hline
\end{tabular}

* See notes regarding research question(s) and results 
Table 5. Who studied: what studied - where

\section{Patient: Patient held maternal and/or child records - developed countries}

\begin{tabular}{|c|c|c|c|c|c|}
\hline & Type of study & Research question* & $\begin{array}{l}\text { Results (positive outcome of having } \\
\text { record) }\end{array}$ & $\begin{array}{l}\text { Results } \\
\text { (neutral) }\end{array}$ & $\begin{array}{l}\text { Results } \\
\text { (negative } \\
\text { outcome of } \\
\text { having } \\
\text { record) }\end{array}$ \\
\hline [64] Draper J, et al. 1986. & $\begin{array}{l}\text { Case controlled } \\
\text { survey }(\# 171)\end{array}$ & $\begin{array}{l}\text { What are Cambridge }(\mathrm{UK}) \\
\text { women's views on carrying } \\
\text { MHR? }\end{array}$ & $\begin{array}{l}\text { Generally positive view ( } 71 / 88 \text { liked } \\
\text { carrying record; } 83 / 88 \text { thought there } \\
\text { were advantages), women appreciate } \\
\text { access to information. }\end{array}$ & & \\
\hline [65] Elbourne D, et al. 1987. & $\begin{array}{l}\text { Randomized } \\
\text { controlled trial } \\
(\# 290)\end{array}$ & $\begin{array}{l}\text { What are women's } \\
\text { preferences for carrying own } \\
\text { MHR (Oxford)? }\end{array}$ & $\begin{array}{l}\text { Positive effects of carrying more } \\
\text { complete record as opposed to notes } \\
\text { are: possibly decreased clerical time, } \\
\text { a greater sense of feeling of control, } \\
\text { confidence talking with medical } \\
\text { personnel. No increase in lost notes } \\
\text { over system. }\end{array}$ & & \\
\hline [66] Lovell A, et al. 1987. & $\begin{array}{l}\text { Randomized } \\
\text { controlled trial } \\
(\# 246)\end{array}$ & $\begin{array}{l}\text { What are women's } \\
\text { preferences for carrying own } \\
\text { MHR (London, UK), and } \\
\text { does carrying own increase } \\
\text { satisfaction with care? }\end{array}$ & $\begin{array}{l}\text { Positive effects of carrying more } \\
\text { complete record as opposed to notes } \\
\text { are: possibly decreased clerical time, } \\
\text { increased feeling of control. } \\
\text { Decrease in lost/mislaid notes ( } 0 \text { for } \\
\text { PHMR) over system }(25 \%) \text {. }\end{array}$ & & \\
\hline [67] Saffin K, et al. 1991. & $\begin{array}{l}\text { Case controlled } \\
\text { survey }(\# 452)\end{array}$ & $\begin{array}{l}\text { How well are children's } \\
\text { records kept by parents, and } \\
\text { do parents who have PHR } \\
\text { (\#284) and those who don't } \\
\text { (\#168) prefer to keep their } \\
\text { children's records } \\
\text { (Oxfordshire)? }\end{array}$ & $\begin{array}{l}\text { Parents who kept their children's } \\
\text { records had more positive view of } \\
\text { practice ( } 75 \% \text { PHR vs. } 26 \% \text { non- } \\
\text { PHR. Appreciated access, } 90 \% \\
\text { PHCR available for audit. }\end{array}$ & & \\
\hline
\end{tabular}




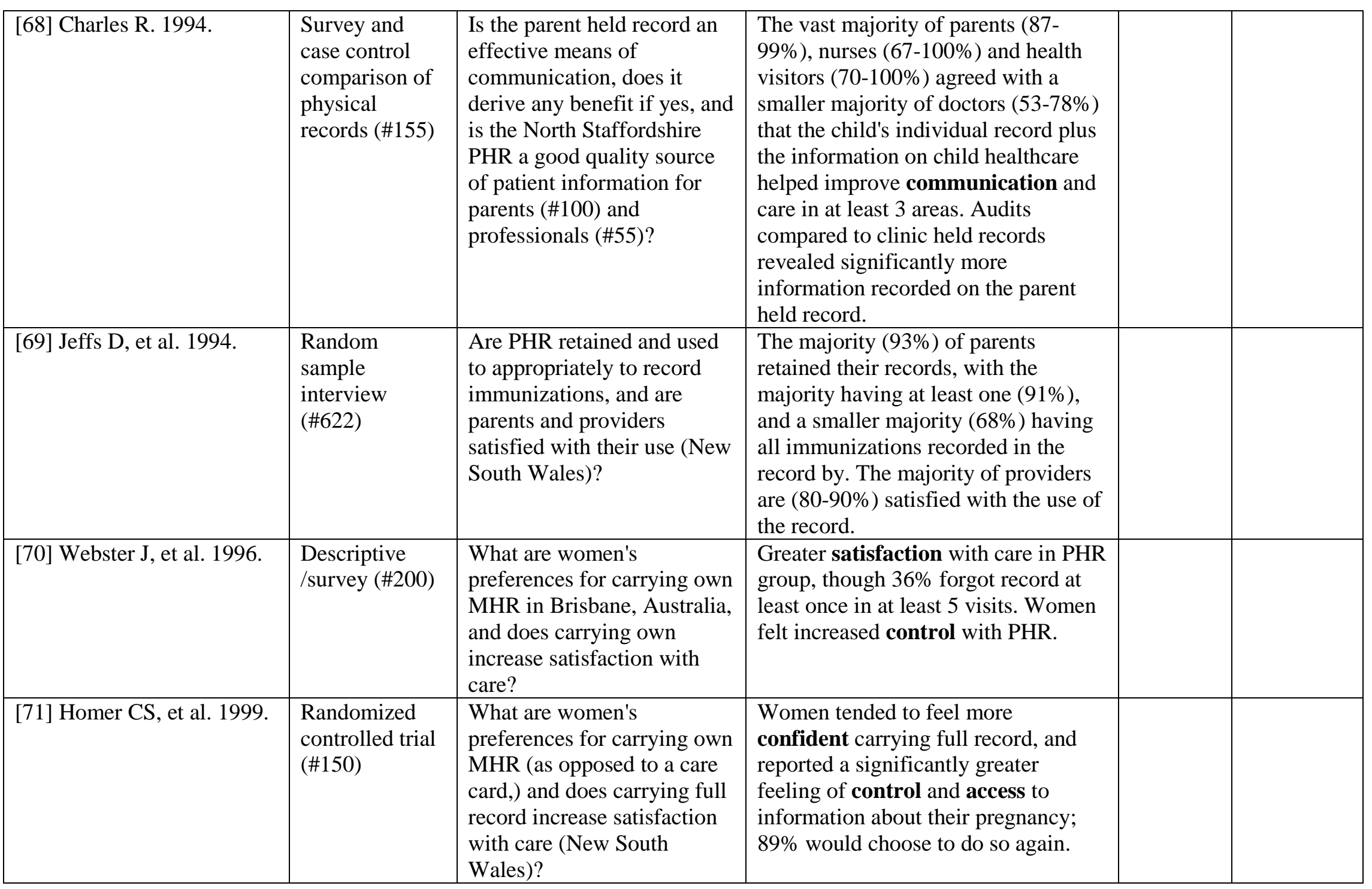


Table 5 (continued) Who studied: what studied - where

Patient: Patient held maternal and/or child records - developed countries

\begin{tabular}{|c|c|c|c|c|c|}
\hline & $\begin{array}{l}\text { Type of } \\
\text { study }\end{array}$ & Research question* & $\begin{array}{l}\text { Results (positive outcome } \\
\text { of having record) }\end{array}$ & Results (neutral) & $\begin{array}{l}\text { Results } \\
\text { (negative } \\
\text { outcome of } \\
\text { having } \\
\text { record) } \\
\end{array}$ \\
\hline [72] Phipps H. 2001. & $\begin{array}{l}\text { Qualitative - } \\
\text { interview } \\
(\# 21)\end{array}$ & $\begin{array}{l}\text { What is impact of } \\
\text { carrying own record } \\
\text { during pregnancy } \\
\text { (Sydney, Australia)? }\end{array}$ & $\begin{array}{l}\text { Great majority of women } \\
\text { favored carrying their own } \\
\text { record in this and } \\
\text { subsequent pregnancy, felt } \\
\text { themselves and family to } \\
\text { be better-informed, } \\
\text { minimal worry about } \\
\text { losing record. }\end{array}$ & & \\
\hline [73] Usha Kiran TS, et al. 2002. & $\begin{array}{l}\text { Prospective } \\
\text { survey (\#72) }\end{array}$ & $\begin{array}{l}\text { What are women's } \\
\text { preferences for } \\
\text { carrying own MHR } \\
\text { and is it an increased } \\
\text { burden (South Wales, } \\
\text { UK)? }\end{array}$ & $\begin{array}{l}\text { The majority }(90.2 \%) \text { of } \\
\text { mothers preferred to carry } \\
\text { own notes; feeling it } \\
\text { improves access to their } \\
\text { case notes. }\end{array}$ & & \\
\hline [74] Shaw E, et al. 2008. & $\begin{array}{l}\text { Randomized } \\
\text { controlled } \\
\text { trial (\#193) }\end{array}$ & $\begin{array}{l}\text { Does secure access to } \\
\text { pre-natal records lead } \\
\text { to higher access to } \\
\text { online information and } \\
\text { greater satisfaction } \\
\text { with care (Hamilton, } \\
\text { Ontario)? }\end{array}$ & $\begin{array}{l}\text { Study group accessed pre- } \\
\text { natal information much } \\
\text { more frequently, and } \\
\text { average of } 8.6 \text { more log- } \\
\text { ins (including own record: } \\
84.2 \% \text { of time) both } \\
\text { groups satisfied with } \\
\text { information provided. }\end{array}$ & & \\
\hline [75] Clendon J, et al. 2010. & $\begin{array}{l}\text { Qualitative - } \\
\text { interview } \\
(\# 35)\end{array}$ & $\begin{array}{l}\text { What is the impact of } \\
\text { the PHCR in New } \\
\text { Zealand }\end{array}$ & $\begin{array}{l}\text { This is a good tool for } \\
\text { improving interaction } \\
\text { between mother and nurse. } \\
\text { Mothers keep the record } \\
\text { for years; sometimes pass }\end{array}$ & & \\
\hline
\end{tabular}


Patient-Held Maternal and/or Child Health Records: Meeting the Information Needs of Patients and Healthcare Providers in Developing Countries?

\begin{tabular}{|c|c|c|c|c|}
\hline & & & $\begin{array}{l}\text { them on to child when } \\
\text { grown. }\end{array}$ & \\
\hline [76] Brown HC, et al. 2004. & $\begin{array}{l}\text { Systematic } \\
\text { review ( } 3 \\
\text { trials) }\end{array}$ & $\begin{array}{l}\text { What are the effects of } \\
\text { having women carry } \\
\text { their own case notes } \\
\text { during pregnancy? }\end{array}$ & $\begin{array}{l}\text { Positive patient view of } \\
\text { more control of care, and } \\
\text { an increased sense of } \\
\text { satisfaction. }\end{array}$ & $\begin{array}{l}\text { Inconclusive health } \\
\text { outcomes }\end{array}$ \\
\hline [77] Bjerkeli Grøvdal L, et al. 2006. & $\begin{array}{l}\text { Randomized } \\
\text { controlled } \\
\text { trial (\#309) }\end{array}$ & $\begin{array}{l}\text { Do PHR have positive } \\
\text { effect on parents' } \\
\text { knowledge, } \\
\text { collaboration with or } \\
\text { utilization of } \\
\text { healthcare in Norway? }\end{array}$ & & $\begin{array}{l}\text { No health effect or } \\
\text { improvement in } \\
\text { other measures } \\
\text { noted by parents. } \\
\text { Majority of parents } \\
\text { carried record. }\end{array}$ \\
\hline
\end{tabular}

* See notes regarding research question(s) and results 


\section{Table 6. Who studied: what studied - where}

Patient: Patient held records in general - developed countries

\begin{tabular}{|c|c|c|c|c|c|}
\hline & $\begin{array}{l}\text { Type of } \\
\text { study }\end{array}$ & $\begin{array}{l}\text { Research question } \\
*\end{array}$ & $\begin{array}{l}\text { Results (positive outcome of } \\
\text { having record) }\end{array}$ & Results (neutral) & $\begin{array}{l}\text { Results } \\
\text { (negative } \\
\text { outcome of } \\
\text { having record) }\end{array}$ \\
\hline [78] Giglio R, et al. 1978. & $\begin{array}{l}\text { Descriptive } \\
\text { /survey }(\# 30)\end{array}$ & $\begin{array}{l}\text { Are people } \\
\text { interested in } \\
\text { carrying their own } \\
\text { PHR (Amherst, } \\
\text { MA)? }\end{array}$ & $\begin{array}{l}\text { Study shows that patients are } \\
\text { willing to make the effort to } \\
\text { carry own card, further study } \\
\text { needed to determine if makes } \\
\text { a difference in outcomes }\end{array}$ & & \\
\hline [79] Liaw ST, et al. 1998. & $\begin{array}{l}\text { Randomized } \\
\text { controlled } \\
\text { trial (\#72) }\end{array}$ & $\begin{array}{l}\text { What is the impact } \\
\text { of a PHR on } \\
\text { responsibility, } \\
\text { information sharing } \\
\text { and preventative } \\
\text { health care of } \\
\text { patients holding a } \\
\text { PHR in Adelaide, } \\
\text { Australia? }\end{array}$ & $\begin{array}{l}\text { Statistically significant } \\
\text { improvement noted in } \\
\text { responsibility and information } \\
\text { sharing of patient, and may } \\
\text { help patient } \\
\text { awareness/participation in } \\
\text { own care. }\end{array}$ & & \\
\hline [80] Jerdén L, et al. 2004. & $\begin{array}{l}\text { Descriptive } \\
\text { /survey } \\
(\# 418)\end{array}$ & $\begin{array}{l}\text { To what extent do } \\
\text { patients report a } \\
\text { lifestyle change } \\
\text { when they have a } \\
\text { PHR? }\end{array}$ & $\begin{array}{l}\text { Swedish study indicates } \\
\text { positive lifestyle changes in } \\
25 \% \text { of those patients who } \\
\text { received an informative health } \\
\text { booklet (and record) }\end{array}$ & & \\
\hline [81] Dickey LL. 1993. & $\begin{array}{l}\text { Literature } \\
\text { review (\#7 } \\
\text { trials) }\end{array}$ & $\begin{array}{l}\text { Have studies shown } \\
\text { any benefit to PHR } \\
\text { for preventative } \\
\text { care? }\end{array}$ & $\begin{array}{l}\text { Some positive benefits for } \\
\text { patient involvement in their } \\
\text { own care in the majority of } \\
\text { studies. Immunization records } \\
\text { for children seem to show the } \\
\text { highest positive value. Future } \\
\text { possibility of electronic } \\
\text { mini-records. }\end{array}$ & & $\begin{array}{l}\text { Potential } \\
\text { barriers include } \\
\text { disruption of } \\
\text { traditional power } \\
\text { barrier, and } \\
\text { perception of } \\
\text { increased time } \\
\text { required. }\end{array}$ \\
\hline
\end{tabular}


Patient-Held Maternal and/or Child Health Records: Meeting the Information Needs of Patients and Healthcare Providers in Developing Countries?

\begin{tabular}{|c|c|c|c|c|c|}
\hline [82] Lecouturier J, et al. 2002. & $\begin{array}{l}\text { Randomized } \\
\text { controlled } \\
\text { trial (\#189) }\end{array}$ & $\begin{array}{l}\text { Does holding own } \\
\text { record increase } \\
\text { cancer patient } \\
\text { satisfaction and } \\
\text { positive feelings } \\
\text { about } \\
\text { communication with } \\
\text { care provider } \\
\text { (Newcastle-upon- } \\
\text { Tyne, UK)? }\end{array}$ & $\begin{array}{l}\text { Healthcare staff had positive } \\
\text { impression. }\end{array}$ & $\begin{array}{l}53 \% \text { with PHR } \\
\text { found it helpful. }\end{array}$ & $\begin{array}{l}\text { Patients with } \\
\text { PHR less } \\
\text { satisfied ( } 58 \% \\
\text { vs. } 86 \% \text { very } \\
\text { satisfied) with } \\
\text { information } \\
\text { given, perhaps } \\
\text { due to higher } \\
\text { expectations. }\end{array}$ \\
\hline [83] Williams JG, et al. 2001. & $\begin{array}{l}\text { Randomized } \\
\text { controlled } \\
\text { trial }(\# 501)\end{array}$ & $\begin{array}{l}\text { Do patients feel } \\
\text { PHR improves } \\
\text { quality of life } \\
\text { (Wales, UK)? }\end{array}$ & $\begin{array}{l}\text { Improved sense of control of } \\
\text { cancer management for some } \\
\text { patients. }\end{array}$ & $\begin{array}{l}\text { No demonstrated } \\
\text { improvement in } \\
\text { quality of life for } \\
\text { cancer } \\
\text { management. } 52 \% \\
\text { of patients would } \\
\text { have preferred not } \\
\text { to have PHR. }\end{array}$ & \\
\hline [84] Drury M, et al. 2000. & $\begin{array}{l}\text { Randomized } \\
\text { controlled } \\
\text { trial }(\# 650)\end{array}$ & $\begin{array}{l}\text { Does holding own } \\
\text { record increase } \\
\text { patient satisfaction } \\
\text { (Oxford)? }\end{array}$ & & $\begin{array}{l}\text { No demonstrated } \\
\text { improvement in } \\
\text { satisfaction for } \\
\text { cancer } \\
\text { management. }\end{array}$ & \\
\hline [85] Cornbleet MA, et al. 2002. & $\begin{array}{l}\text { Randomized } \\
\text { controlled } \\
\text { trial }(\# 244)\end{array}$ & $\begin{array}{l}\text { Does holding own } \\
\text { record increase } \\
\text { cancer patient } \\
\text { satisfaction in urban } \\
\text { Scotland? }\end{array}$ & & $\begin{array}{l}\text { Patients like it, but } \\
\text { no difference } \\
\text { noted on patient } \\
\text { satisfaction and } \\
\text { imposing on the } \\
\text { providers on top of } \\
\text { other records may } \\
\text { be too much on } \\
\text { workload. }\end{array}$ & \\
\hline
\end{tabular}


Table 6 (continued) Who studied: what studied - where

Patient: Patient held records in general - developed countries

\begin{tabular}{|c|c|c|c|c|c|}
\hline & $\begin{array}{l}\text { Type of } \\
\text { study }\end{array}$ & Research question* & $\begin{array}{l}\text { Results } \\
\text { (positive } \\
\text { outcome of } \\
\text { having } \\
\text { record) }\end{array}$ & Results (neutral) & $\begin{array}{l}\text { Results } \\
\text { (negative } \\
\text { outcome of } \\
\text { having } \\
\text { record) }\end{array}$ \\
\hline [86] Lester, H, et al. 2003. & $\begin{array}{l}\text { Randomized } \\
\text { controlled } \\
\text { trial }(\# 201) \\
\end{array}$ & $\begin{array}{l}\text { Do patients in } \\
\text { Birmingham, UK feel } \\
\text { that PHR improves } \\
\text { outcomes? }\end{array}$ & & $\begin{array}{l}\text { No good evidence that PHR helped } \\
\text { schizophrenics, but not apparently } \\
\text { harmful, and a higher symptom score was } \\
\text { associated with not having record. }\end{array}$ & \\
\hline [87] Gysels M, et al. 2007. & $\begin{array}{l}\text { Systematic } \\
\text { review } \quad(\# 12 \\
\text { studies) }\end{array}$ & $\begin{array}{l}\text { Do PHR improve } \\
\text { patient satisfaction } \\
\text { with communication } \\
\text { and information } \\
\text { exchange? }\end{array}$ & & $\begin{array}{l}\text { Extensive literature review into efficacy } \\
\text { of PHR to improve patient satisfaction for } \\
\text { specific cancer patients. Random } \\
\text { controlled trials show different outcomes } \\
\text { (negative/neutral) than qualitative studies } \\
\text { that show a more positive outcome. } \\
\text { Provider attitude and use of PHR seems } \\
\text { important in outcome and efficacy. }\end{array}$ & \\
\hline [88] Ko H, et al. 2010. & $\begin{array}{l}\text { Systematic } \\
\text { review (\#14 } \\
\text { trials) }\end{array}$ & $\begin{array}{l}\text { Is there any } \\
\text { improvement in } \\
\text { outcomes or patient } \\
\text { satisfaction with PHR } \\
\text { in chronic disease } \\
\text { management? }\end{array}$ & & $\begin{array}{l}\text { No demonstrated improvement in } \\
\text { patient satisfaction measures and } \\
\text { communication or care outcomes with } \\
\text { holding PHRs in chronic disease } \\
\text { management in developed countries. }\end{array}$ & \\
\hline
\end{tabular}

* See notes regarding research question(s) and results 


\section{Table 7. Who studied: what studied - where}

Care Provider: Patient held maternal and/or child records - developing countries

\begin{tabular}{|c|c|c|c|c|c|}
\hline & Type of study & Research question* & $\begin{array}{l}\text { Results (positive outcome of having } \\
\text { record) }\end{array}$ & $\begin{array}{l}\text { Results } \\
\text { (neutral) }\end{array}$ & $\begin{array}{l}\text { Results } \\
\text { (negative } \\
\text { outcome of } \\
\text { having } \\
\text { record) }\end{array}$ \\
\hline [89] Kumar V, et al. 1981. & $\begin{array}{l}\text { Descriptive (TBAs } \\
\text { from } 15 \text { villages) }\end{array}$ & $\begin{array}{l}\text { What are features of } \\
\text { record to facilitate } \\
\text { detection of high-risk } \\
\text { pregnancy in India? }\end{array}$ & $\begin{array}{l}\text { Description of card, apparently useful } \\
\text { to help detect risk factors. Benefits } \\
\text { of using for illiterate TBA in order to } \\
\text { aid in earlier detection of risks. }\end{array}$ & & \\
\hline [90] Watson DS. 1984. & $\begin{array}{l}\text { Descriptive survey } \\
(\# 53 \text { notes in } 1980- \\
81 \text { and } \# 60 \text { in } 1982- \\
83)\end{array}$ & $\begin{array}{l}\text { What are features of } \\
\text { record to facilitate } \\
\text { detection of high-risk } \\
\text { pregnancy? }\end{array}$ & $\begin{array}{l}\text { Early record for in-clinic use by } \\
\text { Australian Aboriginal health workers. } \\
\text { Equivalent results to normal records, } \\
\text { results are positive. }\end{array}$ & & \\
\hline [91] Abraham S, et al. 1985. & $\begin{array}{l}\text { House-to house } \\
\text { survey }(\# 400)\end{array}$ & $\begin{array}{l}\text { What features of } \\
\text { record are needed to } \\
\text { improve quality of } \\
\text { care and improve } \\
\text { record keeping } \\
\text { (Vellore, India)? }\end{array}$ & $\begin{array}{l}\text { MCHCC evaluation reveals positive } \\
\text { effects on quality of care, detecting } \\
\text { risks. Improvement needed in } \\
\text { stressing importance for educating } \\
\text { mothers/families, as } 7 \% \text { of mothers } \\
\text { lost record and } 18 \% \text { discarded it } \\
\text { following sterilization. }\end{array}$ & & \\
\hline [92] Abraham S, et al. 1991. & $\begin{array}{l}\text { Non-randomized } \\
\text { control (\#2446) }\end{array}$ & $\begin{array}{l}\text { Does provision of } \\
\text { PHMR card improve } \\
\text { outcomes in } \\
\text { pregnancies in rural } \\
\text { India? }\end{array}$ & $\begin{array}{l}\text { Some positive outcomes for referral } \\
\text { and knowledge of people involved- } \\
\text { knowledge higher for most measures } \\
\text { in women with PHMR. Good } \\
\text { acceptance by families, but } \\
\text { suggestions for greater acceptance. }\end{array}$ & & \\
\hline [24] Shah PM, et al. 1993. & $\begin{array}{l}\text { Large, multi-center } \\
\text { collaborative } \\
\text { comparative } \\
\text { pre/post } \\
\text { intervention study } \\
\text { (\#13 in \#8 }\end{array}$ & $\begin{array}{l}\text { Evaluate the function } \\
\text { of the PHMR } \\
\text { following set of } \\
\text { WHO guidelines. }\end{array}$ & $\begin{array}{l}\text { Substantial improvement in maternal } \\
\text { and neonatal care, and continuity of } \\
\text { care in areas using PHMR (examples: } \\
\text { Philippines } 91-100 \% \text { vs. } 36.6-51.9 \% \text {; } \\
\text { Zambia } 93.5 \% \text { vs. } 49.8 \% \text { ). Records } \\
\text { adapted to local situation. }\end{array}$ & & \\
\hline
\end{tabular}


Patient-Held Maternal and/or Child Health Records: Meeting the Information Needs of Patients and Healthcare Providers in Developing Countries?

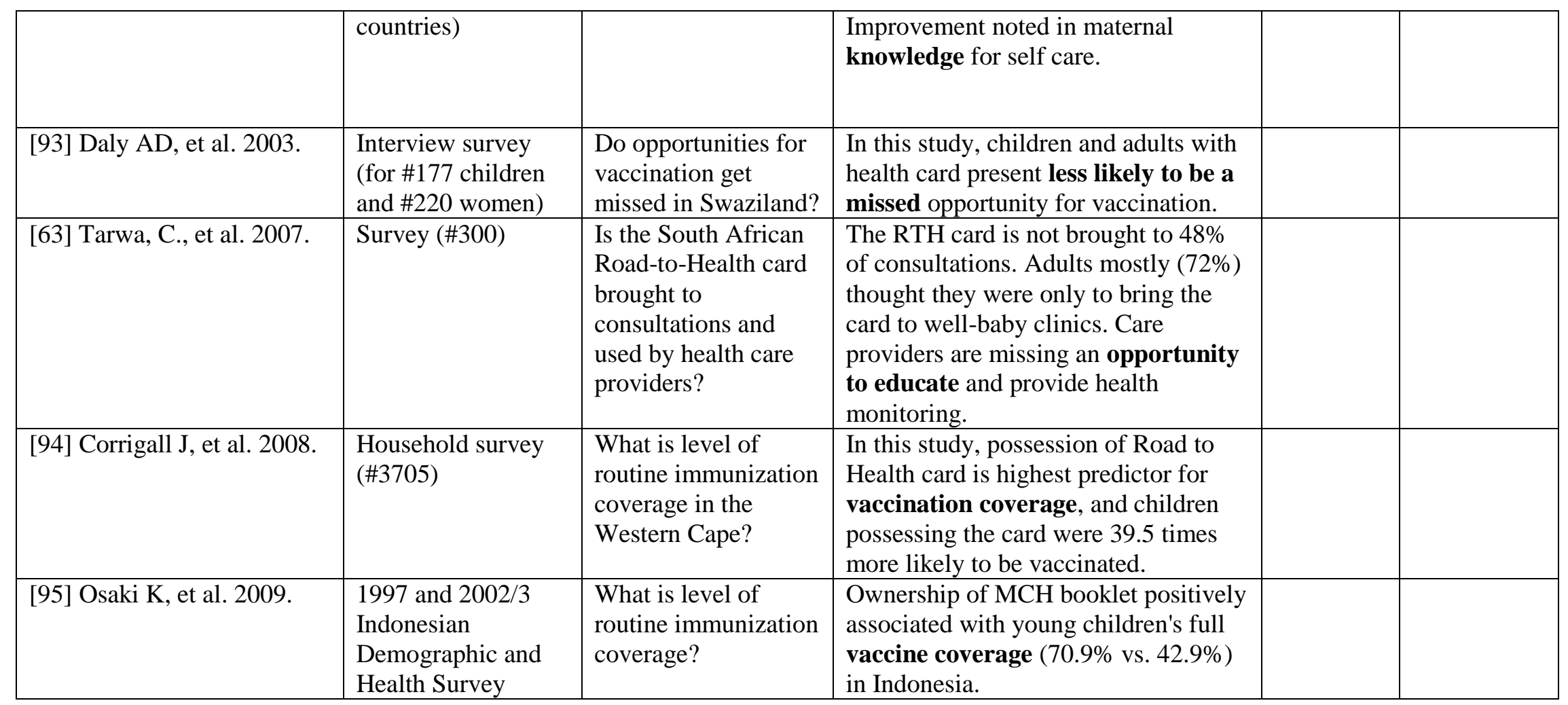


Table 7 (continued) Who studied: what studied - where

Care Provider: Patient held maternal and/or child records - developing countries

\begin{tabular}{|c|c|c|c|c|c|}
\hline & Type of study & Research question* & $\begin{array}{l}\text { Results (positive } \\
\text { outcome of having } \\
\text { record) }\end{array}$ & Results (neutral) & $\begin{array}{l}\text { Results } \\
\text { (negative } \\
\text { outcome } \\
\text { of having } \\
\text { record) }\end{array}$ \\
\hline [96] Mukanga DO, et al. 2006. & $\begin{array}{l}\text { Random } \\
\text { household } \\
\text { interview survey } \\
(\# 260)\end{array}$ & $\begin{array}{l}\text { What factors contribute to } \\
\text { family having and retaining } \\
\text { PHCR in Uganda? }\end{array}$ & $\begin{array}{l}\text { There is a positive } \\
\text { relation to } \\
\text { improved health } \\
\text { with card retention. } \\
\text { Children with a } \\
\text { card were } 10 \text { times } \\
\text { as likely to be fully } \\
\text { immunized. }\end{array}$ & $\begin{array}{l}\text { Mothers don't receive } \\
\text { card as frequently if they } \\
\text { don't use a health care } \\
\text { center. Children } \\
\text { delivered at a healthcare } \\
\text { facility were } 4 \text { times as } \\
\text { likely to have card; } \\
\text { children who had been } \\
\text { to a facility in the past } 3 \\
\text { months were } 2 \text { times as } \\
\text { likely to have card. }\end{array}$ & \\
\hline [97] Chabot HT, et al. 1990. & $\begin{array}{l}\text { Literature review } \\
\text { and descriptive } \\
\text { survey }\end{array}$ & $\begin{array}{l}\text { Would including pictorial } \\
\text { and written risk indicators } \\
\text { make a single PHMR more } \\
\text { useable for ALL prenatal } \\
\text { caregivers? }\end{array}$ & & $\begin{array}{l}\text { Includes literature } \\
\text { review of current MHR } \\
\text { in use and suggestions } \\
\text { for single card usable for } \\
\text { both literate and illiterate } \\
\text { health care providers to } \\
\text { allow mother to carry } \\
\text { only one card. Area } \\
\text { determines different } \\
\text { procedures done by } \\
\text { each. Example from } \\
\text { Mali. }\end{array}$ & \\
\hline [98] Kumar R. 1993. & $\begin{array}{l}\text { Descriptive/ } \\
\text { interview (\#14) }\end{array}$ & $\begin{array}{l}\text { Does the simplified MHR } \\
\text { improve workload and } \\
\text { improve statistical reporting } \\
\text { in rural India? }\end{array}$ & & $\begin{array}{l}\text { The simplification } \\
\text { decreased the workload } \\
\text { for healthcare workers, } \\
\text { but no or minimal } \\
\text { improvement in }\end{array}$ & \\
\hline
\end{tabular}


Patient-Held Maternal and/or Child Health Records: Meeting the Information Needs of Patients and Healthcare Providers in Developing Countries?

\begin{tabular}{|c|c|c|c|}
\hline & & & $\begin{array}{l}\text { reporting of vital } \\
\text { statistics. }\end{array}$ \\
\hline [99] Goldman N, et al. 1994. & $\begin{array}{l}\text { Data from the } \\
1987 \text { Encuesta } \\
\text { Nacional de } \\
\text { Salud Materno } \\
\text { Infantil (National } \\
\text { Survey) }\end{array}$ & $\begin{array}{l}\text { How does the official } \\
\text { government record of } \\
\text { immunization in Guatemala } \\
\text { compare with PHR and } \\
\text { maternal recall for obtaining } \\
\text { a more accurate view of } \\
\text { immunization levels? }\end{array}$ & $\begin{array}{l}\text { Compares (with great } \\
\text { limitation) data obtained } \\
\text { from the card as opposed } \\
\text { to maternal recall-is } \\
\text { likely to be at least as/or } \\
\text { more accurate than the } \\
\text { government (potentially } \\
\text { overestimated record). }\end{array}$ \\
\hline [61] Harrison D, et al. 1998. & $\begin{array}{l}\text { Descriptive / } \\
\text { interview (\#185) }\end{array}$ & $\begin{array}{l}\text { What are the opinions of } \\
\text { mothers/caregivers (\#150) } \\
\text { and health care providers } \\
\text { (\#35) regarding accuracy } \\
\text { and completeness of the } \\
\text { Road to Health card in Cape } \\
\text { Town, South Africa? }\end{array}$ & $\begin{array}{l}\text { Most health care } \\
\text { providers }(80 \%) \text { support } \\
\text { the concept, but most } \\
(80 \%) \text { would like } \\
\text { information to be in a } \\
\text { more useful format. } \\
\text { Points out need to } \\
\text { determine what } \\
\text { information is important } \\
\text { to family and healthcare } \\
\text { providers in order for } \\
\text { them to actually fill out } \\
\text { all information. }\end{array}$ \\
\hline [100] Nuwaha F, et al. 2000. & $\begin{array}{l}\text { Retrospective } \\
\text { comparison of } \\
\text { national survey }\end{array}$ & $\begin{array}{l}\text { Did immunization levels } \\
\text { improve after introduction } \\
\text { of vaccination cards and } \\
\text { Vitamin A supplementation } \\
\text { in Uganda? }\end{array}$ & $\begin{array}{l}\text { Immunization cards may } \\
\text { have been seen as proof } \\
\text { of vaccination and } \\
\text { caring parent. People } \\
\text { with cards seemingly get } \\
\text { better care. Vaccine } \\
\text { levels increased after } \\
\text { introduction of cards and } \\
\text { vitamin A } \\
\text { supplementation, though } \\
\text { causality could not be } \\
\text { determined. }\end{array}$ \\
\hline
\end{tabular}

* See notes regarding research question(s) and results 


\section{Table 8. Who studied: what studied - where}

Care Provider: Patient held maternal and/or child records - developed countries

\begin{tabular}{|c|c|c|c|c|c|}
\hline & $\begin{array}{l}\text { Type of } \\
\text { study }\end{array}$ & $\begin{array}{l}\text { Research } \\
\text { question* }\end{array}$ & $\begin{array}{l}\text { Results } \\
\text { (positive outcome } \\
\text { of having record) }\end{array}$ & $\begin{array}{l}\text { Results } \\
\text { (neutral) }\end{array}$ & $\begin{array}{l}\text { Results } \\
\text { (negative outcome } \\
\text { of having record) }\end{array}$ \\
\hline [101] McElligott JT, et al. 2010. & $\begin{array}{l}\text { Government- } \\
\text { provided data } \\
\text { analysis }\end{array}$ & $\begin{array}{l}\text { Are PHR for } \\
\text { childhood } \\
\text { immunizations } \\
\text { positively } \\
\text { correlated with } \\
\text { being up-to-date } \\
\text { on vaccines? }\end{array}$ & $\begin{array}{l}\text { In US, especially } \\
\text { with more } \\
\text { disadvantaged } \\
\text { families, holding } \\
\text { vaccination record } \\
\text { associated with } \\
\text { higher rates of } \\
\text { immunization; } \\
\text { odds for child being } \\
\text { up-to-date } \\
\text { determined as } 62 \% \\
\text { greater for children } \\
\text { with PHR. }\end{array}$ & & \\
\hline [102] MacFarlane A, et al. 1990. & $\begin{array}{l}\text { Retrospective } \\
\text { study (\#239) }\end{array}$ & $\begin{array}{l}\text { What are the } \\
\text { reactions of } \\
\text { general } \\
\text { practitioners and } \\
\text { health visitors of } \\
\text { PHCR? }\end{array}$ & $\begin{array}{l}\text { In Oxfordshire, the } \\
\text { majority of } \\
\text { providers (over } \\
90 \% \text { ) with } \\
\text { experience with } \\
\text { PHR have positive } \\
\text { response to PHCR } \\
\text { due to ability to } \\
\text { access information, } \\
\text { minimal experience } \\
\text { of loss. Providers } \\
\text { WITHOUT } \\
\text { experience much } \\
\text { more uncertain, only }\end{array}$ & & \\
\hline
\end{tabular}


Patient-Held Maternal and/or Child Health Records: Meeting the Information Needs of Patients and Healthcare Providers in Developing Countries?

\begin{tabular}{|c|c|c|c|c|c|}
\hline & & & $\begin{array}{l}59 \% \text { view PHR } \\
\text { positively. }\end{array}$ & & \\
\hline [103] Toohill J, et al. 2006. & $\begin{array}{l}\text { Audit /survey } \\
(\# 1256)\end{array}$ & $\begin{array}{l}\text { Are PHMR } \\
\text { returned with } \\
\text { mother at time of } \\
\text { delivery, and does } \\
\text { education improve } \\
\text { return rate } \\
\text { (Australia)? }\end{array}$ & $\begin{array}{l}\text { The majority of } \\
\text { mothers returned } \\
\text { their records. } \\
\text { Compliance } \\
\text { numbers increased } \\
\text { over time with } \\
\text { education on } \\
\text { importance of } \\
\text { recordkeeping ( } 82 \text { to } \\
88.5 \% \text { increase in } \\
\text { compliance). }\end{array}$ & $\begin{array}{l}\text { There were } \\
\text { some issues for } \\
\text { healthcare } \\
\text { providers for } \\
\text { maintaining } \\
\text { record } \\
\text { completeness if } \\
\text { record not } \\
\text { available. }\end{array}$ & \\
\hline [69] Jeffs D, et al. 1994. & $\begin{array}{l}\text { Random } \\
\text { sample } \\
\text { interview } \\
(\# 622)\end{array}$ & $\begin{array}{l}\text { Are PHR retained } \\
\text { and used to } \\
\text { appropriately to } \\
\text { record } \\
\text { immunizations, } \\
\text { and are parents } \\
\text { and providers } \\
\text { satisfied with their } \\
\text { use (New South } \\
\text { Wales)? }\end{array}$ & $\begin{array}{l}\text { The majority (93\%) } \\
\text { of parents retained } \\
\text { their records, with } \\
\text { the majority having } \\
\text { at least one }(91 \%) \text {, } \\
\text { and a smaller } \\
\text { majority }(68 \%) \\
\text { having all } \\
\text { immunizations } \\
\text { recorded in the } \\
\text { record by. The } \\
\text { majority of } \\
\text { providers are (80- } \\
90 \%) \text { satisfied with } \\
\text { the use of the } \\
\text { record. }\end{array}$ & $\begin{array}{l}\text { A smaller than } \\
\text { hoped for } \\
\text { number of } \\
\text { providers (29- } \\
79 \% \text { ) had the } \\
\text { purpose of the } \\
\text { PHR explained } \\
\text { to them, and a } \\
\text { wide range in } \\
\text { the } \\
\text { professionals } \\
\text { who used the } \\
\text { records (30- } \\
96 \% \text { ). }\end{array}$ & \\
\hline
\end{tabular}




\begin{tabular}{|c|c|c|c|c|}
\hline [68] Charles R. 1994. & $\begin{array}{l}\text { Survey and } \\
\text { case control } \\
\text { comparison of } \\
\text { physical } \\
\text { records } \\
(\# 155)\end{array}$ & $\begin{array}{l}\text { Is the parent held } \\
\text { record an effective } \\
\text { means of } \\
\text { communication, } \\
\text { does it derive any } \\
\text { benefit if yes, and } \\
\text { is the North } \\
\text { Staffordshire PHR } \\
\text { a good quality } \\
\text { source of patient } \\
\text { information for } \\
\text { parents (\#100) and } \\
\text { professionals } \\
\text { (\#55)? }\end{array}$ & $\begin{array}{l}\text { The vast majority of } \\
\text { parents (87-99\%), } \\
\text { nurses (67-100\%) } \\
\text { and health visitors } \\
\text { (70-100\%) agreed } \\
\text { with a smaller } \\
\text { majority of doctors } \\
\text { (53-78\%) that the } \\
\text { child's individual } \\
\text { record plus the } \\
\text { information on child } \\
\text { healthcare helped } \\
\text { improve } \\
\text { communication } \\
\text { and care in at least } \\
3 \text { areas. Audits } \\
\text { compared to clinic } \\
\text { held records } \\
\text { revealed } \\
\text { significantly more } \\
\text { information } \\
\text { recorded on the } \\
\text { parent held record. }\end{array}$ & $\begin{array}{l}\text { Doctors expressed } \\
\text { concerns about } \\
\text { maintaining } \\
\text { confidentiality, } \\
\text { extra burden of } \\
\text { work in } \\
\text { maintaining the } \\
\text { records, the size of } \\
\text { the record and fears } \\
\text { that patients } \\
\text { wouldn't bring the } \\
\text { record to clinic } \\
\text { visits (this final } \\
\text { concern may be } \\
\text { dispelled by the } \\
\text { increased amount } \\
\text { of information } \\
\text { recorded in the } \\
\text { PHR). }\end{array}$ \\
\hline
\end{tabular}


Table 8 (continued) Who studied: what studied - where

Care Provider: Patient held maternal and/or child records - developed countries

\begin{tabular}{|c|c|c|c|c|c|}
\hline & Type of study & Research question* & $\begin{array}{l}\text { Results } \\
\text { (positive } \\
\text { outcome of } \\
\text { having } \\
\text { record) }\end{array}$ & Results (neutral) & $\begin{array}{l}\text { Results } \\
\text { (negative outcome } \\
\text { of having record) }\end{array}$ \\
\hline [76] Brown HC, et al. 2004. & $\begin{array}{l}\text { Systematic } \\
\text { review (3 } \\
\text { studies) }\end{array}$ & $\begin{array}{l}\text { What are the effects of } \\
\text { having women carry their } \\
\text { own case notes during } \\
\text { pregnancy? }\end{array}$ & & $\begin{array}{l}\text { Inconclusive health } \\
\text { outcomes. Providers } \\
\text { report an increase in } \\
\text { the number of } \\
\text { surgical interventions } \\
\text { with women carrying } \\
\text { their PHR. This } \\
\text { might be a positive } \\
\text { finding in developing } \\
\text { countries where the } \\
\text { problem is lack of } \\
\text { intervention in high- } \\
\text { risk cases. }\end{array}$ & $\begin{array}{l}\text { Providers report an } \\
\text { increase in the } \\
\text { number of surgical } \\
\text { interventions with } \\
\text { women carrying } \\
\text { their PHR. This } \\
\text { might be a positive } \\
\text { finding in } \\
\text { developing countries } \\
\text { where the problem } \\
\text { is lack of } \\
\text { intervention in high- } \\
\text { risk cases. }\end{array}$ \\
\hline [104] Wilkinson SA, et al. 2007. & $\begin{array}{l}\text { Descriptive - } \\
\text { survey (\#7) } \\
\text { /review } \\
\text { discussion } \\
(\# 25+)\end{array}$ & $\begin{array}{l}\text { What are the effects of } \\
\text { having women carry a } \\
\text { new enhanced record } \\
\text { during pregnancy } \\
\text { (Queensland)? }\end{array}$ & & & $\begin{array}{l}\text { Care providers felt } \\
\text { that the new record } \\
\text { was too large for the } \\
\text { patient to carry, and } \\
\text { contained too much } \\
\text { information to be } \\
\text { useful to mother. } \\
\text { Suggested a smaller } \\
\text { patient-centered } \\
\text { document for } \\
\text { mother, and full } \\
\text { record to be kept in } \\
\text { clinic. }\end{array}$ \\
\hline
\end{tabular}

* See notes regarding research question(s) and results 


\section{Table 9. Who studied: what studied - where}

Care Provider: Patient held records in general - developed countries

\begin{tabular}{|c|c|c|c|c|c|}
\hline & Type of study & $\begin{array}{l}\text { Research } \\
\text { question* }\end{array}$ & $\begin{array}{l}\text { Results } \\
\text { (positive outcome } \\
\text { of having record) }\end{array}$ & Results (neutral) & $\begin{array}{l}\text { Results } \\
\text { (negative } \\
\text { outcome } \\
\text { of having } \\
\text { record) }\end{array}$ \\
\hline i. [81] Dickey LL. 1993. & $\begin{array}{l}\text { Quasi experimental comparison } \\
(\# 25)\end{array}$ & $\begin{array}{l}\text { Is patient } \\
\text { compliance } \\
\text { with preventive } \\
\text { care guidelines } \\
\text { improved with } \\
\text { PHR (San } \\
\text { Francisco, } \\
\text { CA)? }\end{array}$ & $\begin{array}{l}\text { Some positive } \\
\text { benefits noted by } \\
54-82 \% \text { of care- } \\
\text { providers for } 7 \\
\text { separate } \\
\text { parameters, with } \\
\text { increased } \\
\text { compliance } \\
\text { providing } \\
\text { preventative care } \\
\text { in study groups } \\
\text { (9.3-11.6\% higher } \\
\text { compliance than } \\
\text { control). }\end{array}$ & & \\
\hline [105] Atkin PA, et al. 1995. & Prospective survey (\#187) & $\begin{array}{l}\text { Are medication } \\
\text { PHR cards used } \\
\text { (Sydney, } \\
\text { Australia)? }\end{array}$ & & $\begin{array}{l}\text { For older population } \\
\text { in Sydney, Australia, } \\
\text { medication cards } \\
\text { don't seem to be used } \\
\text { (presentation of card } \\
\text { dropped from } 61 \% \text { to } \\
23 \% \text { over } 12 \text { months) } \\
\text { or improve } \\
\text { compliance in } \\
\text { research population } \\
\text { ( } 21 \% \text { of users said } \\
\text { card helpful). }\end{array}$ & \\
\hline
\end{tabular}


Patient-Held Maternal and/or Child Health Records: Meeting the Information Needs of Patients and Healthcare Providers in Developing Countries?

\begin{tabular}{|l|l|l|l|}
\hline [106] Dijkstra RF, et al. 2005. & Randomized controlled trial (\#769) & $\begin{array}{l}\text { Does PHR } \\
\text { improve quality } \\
\text { of care for } \\
\text { diabetes } \\
\text { patients in the } \\
\text { Netherlands? }\end{array}$ & $\begin{array}{l}\text { Modest } \\
\text { improvements in } \\
\text { patient health } \\
\text { parameters. } \\
\text { Disappointing results } \\
\text { on maintaining card, } \\
36 \% \text { using card at } \\
\text { end of study. }\end{array}$ \\
\hline
\end{tabular}

* See notes regarding research question(s) and results 


\section{Discussion}

\section{A. Maternal Information Behavior}

Though the number of information behavior studies located in this literature review is quite limited [34-47], the sense one gets from them is that families, in particular mothers in developing countries, are interested in information about healthcare issues for their family. While these studies come from different countries and regions of the world, they show some interesting similarities. Generalization of mothers' information behavior is not possible due to the small number of studies and participants. In the studies that measure all types of information seeking behavior, health information needs rank high in the list of overall women's information needs in developing countries $[34,35,38,39]$. The few studies that look specifically at health information seeking behavior in these populations [36, 37, 40], show that mothers studied in the developing countries tend to seek medical information and advice for their children and families more commonly than searching for other information needs, and the first or most common source for information comes from other people. There is some indication that these mothers are interested in information regarding child development and care. Another common theme in the studies from both developed and developing countries is that mothers from diverse backgrounds prefer to receive health information directly from their healthcare provider. The one exception to this might be mothers in the population of adolescents in sub-Saharan Africa [41], though it is also possible that the nature of the information or the population involved lends itself to a different preferred mode of delivery.

These findings lead one to consider very carefully how mothers might use a home-based healthcare record as a source of information regarding their own and their children's care. The literature retrieved in this review puts forward the idea that pregnant women and mothers from all different societies, both developing and developed, show a preference for receiving health information from a person, whether a healthcare provider or not. It seems likely, that unless there is a demographic shift in information behavior, mothers may not choose to use information provided in any format of healthcare record. Instead they may continue to seek out interpersonal sources.

\section{B. Maternal and/or Child Healthcare Record}

The earliest studies retrieved regard maternal and child healthcare records in developing countries, and mainly consist of how-to diagrams with the care provider/designer demonstrating their ideas about creation of these records. Due to the descriptive nature of most of the articles listed in Table 3, the assumption was made that they reflected the information needs of their healthcare provider and agency creators. The information needs of healthcare providers and other healthcare agencies must be inferred from the proposals and guidelines developed for the production of maternal and/or child healthcare records. The progression shows some measure of the evolution of these records over time [24-26, 47-52].

The other studies retrieved from the search in all categories (Tables 4-9), delve into the usefulness and outcomes of the patient-held record. Very few negative results noted for either healthcare provider or patient in the patient-held record. In the patient-effected categories 
(Tables 4-6), the most patient-noted positive effect in developing countries was the increased knowledge of the benefits of healthcare, as well as having the records available when needed $[59,60]$. A lack of understanding of the record's use pointed to a need for greater education in studies where the patient effect was neutral [61-63]. The effect of the patient-held record seems most positive on patients holding maternal and/or child records in developed countries. These mothers, for the most part, tend to relate positive feelings of confidence, control, access (feeling better informed), satisfaction, and improved communication and interaction during the healthcare process (Table 5). As mothers in developing countries become better informed and want to play a greater role in their own care, perhaps carrying their own maternal/child records can engender these same feelings. In contrast to mother and child records, most other patient held records have not shown to be of significant benefit to either the patient or the healthcare provider (Tables 6 and 9).

The results for the influence of patient-held records on care providers was more mixed (Tables 7-9). Care providers in developing countries seemed to recognize the most positive outcomes in terms of improving health and prevention practices with patients carrying the maternal and/or child record (Table 7). Though follow-up study needs to continue, the improvements noted for patients are encouraging. In addition, the majority of studies, where this was measured [59, 63, $65-70,72,75,77,80,91,94,96,103]$, showed that patients tend not to lose patient-held maternal and/or child records, though some of the general patient-held records were more readily lost to follow-up [105, 106]. This finding seems significant and may be worth continued study in determining the importance of these records, especially to families in developing countries.

In general, these studies show some positive outcomes related to the use of the patient-held maternal and/or child record. The most positive effects relate to the patient's (mother) emotional state and feelings of control and access to information, particularly in developed countries, and results of improved health outcomes with the patient-held maternal and/or child record in developing countries. The fact still remains that 49 of the 68 priority countries are not on track to reach the UN Millennium Development Goals for 2015 [15], and these positive results need to be further leveraged to help developing countries meet their goals for decreasing mortality and improving health.

\section{Study Limitations}

The results obtained in the literature review may have suffered, both from the inability to find all applicable research in the field, as well from a limited time frame for study. In particular, it was impossible to pursue all potential sources for research in information behavior and patient-held records. The research questions addressed in the studies on patient-held records retrieved from the literature search were quite varied, and therefore difficult to compare aside from impressions of the effect or influence of the record on the patient and/or care provider. In addition, several of the studies produced mixed results, further confusing the comparison. Finally, reviewer bias, access to articles and limitations to the English language inevitably factored into which search avenues were pursued and which articles were included in the study. 


\section{Recommendations}

The information behavior of women, particularly in developing countries, needs further investigation. It is unclear whether the childcare and healthcare information provided in existing patient held, maternal-child healthcare records, such as the Kenyan Maternal \& Child Health Booklet [31] and others [27], meets the needs of mothers and families. The literature suggests that pregnant women and mothers (Tables 1 and 2) prefer to seek information from human sources. In particular, mothers appear to prefer to receive information from healthcare providers. Healthcare providers must also be included in any discussion of maternal-child healthcare records; providers' input on needed data is crucial to the success of any healthcare record (Table 3).

Several studies have demonstrated the use of mobile technology, such as cell phones and personal digital assistants (PDA), in healthcare in both the developed [105-111] and developing [112-115] world. Protocols have been developed for creating healthcare forms and questionnaires for small mobile devices [114, 116-118]. The technology currently exists for enhancing patient-held records for storage on web-enabled mobile devices [113, 119]. Healthcare providers currently use short message services (SMS) to send targeted health-related messages to their patients $[109,115,120]$. In addition, electronic devices allow for communication beyond just text and the pictorial representation allowed by paper records; cell phones allow for photographic and graphic visual display, as well as voice and text messaging, electronic storage, and two-way capabilities [121, 122]. The next step in evaluating the appropriateness of web-enabled cell technology for a patient-held maternal-child healthcare record in developing countries is to determine whether a mobile platform can meet the information needs of women and families, as well as the healthcare providers in the region. Currently a pilot study is underway in Peru to "[d]evelop an interactive computer-based system and a common mobile phone-based platform to support maternal and child care among pregnant women" [123]. This project, a public-private partnership, also hopes to improve health services to pregnant women by increasing access to timely information, allowing greater monitoring capability by the health system, and finding empirical evidence of the social and economic impacts of mobile technologies. Going forward, further research is needed to explore the utility of providing targeted health messages to mothers regarding their own health and that of their children. Additionally, an assessment of the infrastructure and current practices must be complete to determine if this might best be accomplished through mobile technologies [124, $125]$. 


\section{Conclusions}

Information behavior of women, in particular disadvantaged pregnant women and mothers in developed and developing countries and other caregivers in developing countries, seems to rely most commonly on seeking information from interpersonal sources. For health-related information, most of these women look to healthcare providers. More study is necessary to determine if delivering health information in an alternative format would be acceptable or well received.

The development of maternal-child healthcare records in developing countries over time offers the best insight into the basic information needs of maternal-child healthcare providers. The presence of a maternal and/or child healthcare record appears to have a positive effect, for the most part, on both care providers and patients in developing countries. In addition, the presence of a maternal and/or child healthcare record appears to have a positive effect, for the most part, on patients' sense of control and feelings of satisfaction in developed countries. Other types of patient-held records, in developed countries in particular, have not been as positively received.

\section{Notes}

Due to space limitations, it was necessary to restate and/or paraphrase research questions and study results listed in the tables above. The first author is responsible for interpreting research questions gleaned from the abstract, introduction and/or problem sections of the articles reviewed. The first author is also responsible for the interpretation and inclusion (or exclusion) of results obtained from the abstract and/or results sections of the articles reviewed.

\section{Acknowledgements}

I would like to thank Sherrilynne Fuller and Grace John Stewart, MD, PhD, MPH and other members of the Center for Integrated Health of Women, Children, and Adolescents at the University of Washington for suggesting I pursue this literature review as the culminating project of my MLIS degree. In addition I'd like to thank my family for enduring the many weeks of my "absence" while completing this project. 
Patient-Held Maternal and/or Child Health Records: Meeting the Information Needs of Patients and Healthcare Providers in Developing Countries?

\section{References}

[1] World Health Organization. Media Center: Millennium Development Goals: progress towards the health-related Millennium Development Goals [Internet]. [place unknown]: World Health Organization; c2011 [updated 2010 May; cited 2011 Mar 18]. Available from: http://www.who.int/mediacentre/factsheets/fs290/en/.

[2] World Health Organization. Department of Child and Adolescent Health Development. Highlights: Child and adolescent health and development progress report 2006-2007. Geneva: WHO Press; 2008. 21 p.

[3] World Health Organization. Department of Child and Adolescent Health Development. Highlights: Child and adolescent health and development progress report 2009. Geneva: WHO Press; 2010. 41 p.

[4] World Health Organization. Maternal Health and Safe Motherhood Programme, Division of Family Health. Mother-Baby Package: Implementing safe motherhood in countries. Geneva: World Health Organization; 1994 [cited 2011 Mar 18]. 89 p. Available from: http://whqlibdoc.who.int/hq/1994/WHO_FHE_MSM_94.11_Rev.1.pdf.

[5] Mturi AJ, Curtis SL. The determinants of infant and child mortality in Tanzania. Health Policy Plan. 1995 Dec;10(4):384-94. Review. PubMed PMID: 10154361.

[6] World Health Organization. Pregnant women and antenatal care. Weekly Epidemiological Record. 2004 Apr 2;149(79):143-44.

[7] Akukwe C. Maternal and child health services in the twenty-first century: critical issues, challenges, and opportunities. Health Care Women Int. 2000 Oct-Nov;21(7):641-53. Review. PubMed PMID: 11813771.

[8] Akukwe C, Nowell AH. Essential strategies for achieving durable population-based maternal and child health services. J R Soc Promot Health. 1999 Mar;119(1):42-9. PubMed PMID: 10327815.

[9] Patton GC, Coffey C, Sawyer SM, Viner RM, Haller DM, Bose K, Vos T, Ferguson J, Mathers CD. Global patterns of mortality in young people: a systematic analysis of population health data. Lancet. 2009 Sep 12;374(9693):881-92. PubMed PMID: 19748397.

[10] McTavish S, Moore S, Harper S, Lynch J. National female literacy, individual socioeconomic status, and maternal health care use in sub-Saharan Africa. Soc Sci Med. 2010 Dec;71(11):1958-63. Epub 2010 Sep 29. PubMed PMID: 20980089.

[11] Banta D. What is the efficacy/effectiveness of antenatal care and the financial and organizational implications? Copenhagen: WHO Regional Office for Europe (Health Evidence Network report; 2003 Dec. [cited 2011 Mar 18]. Available from: http://www.euro.who.int/Document/E82996.pdf.

[12] Hill Z, Kirkwood B, Edmond K. Family and community practices that promote child survival, growth and development. Geneva: World Health Organization; 2004. 133 p.

[13] Kwast BE. Reduction of maternal and perinatal mortality in rural and peri-urban settings: what works? Eur J Obstet Gynecol Reprod Biol. 1996 Oct;69(1):47-53. Review. PubMed PMID: 8909956. 
Patient-Held Maternal and/or Child Health Records: Meeting the Information Needs of Patients and Healthcare Providers in Developing Countries?

[14] Kwast BE. Quality of care in reproductive health programmes: monitoring and evaluation of quality improvement. Midwifery. 1998 Dec;14(4):199-206. Review. PubMed PMID: 10076314.

[15] Bhutta ZA, Chopra M, Axelson H, Berman P, Boerma T, Bryce J, Bustreo F, Cavagnero E, Cometto G, Daelmans B, de Francisco A, Fogstad H, Gupta N, Laski L, Lawn J, Maliqi B, Mason E, Pitt C, Requejo J, Starrs A, Victora CG, Wardlaw T. Countdown to 2015 decade report (2000-10): taking stock of maternal, newborn, and child survival. Lancet. 2010 Jun 5;375(9730):2032-44. Review. Erratum in: Lancet. 2010 Sep 4;376(9743):772. PubMed PMID: 20569843.

[16] Bhutta ZA, Darmstadt GL, Hasan BS, Haws RA. Community-based interventions for improving perinatal and neonatal health outcomes in developing countries: a review of the evidence. Pediatrics. 2005 Feb;115(2 Suppl):519-617. Review. PubMed PMID: 15866863.

[17] Chopra M, Daviaud E, Pattinson R, Fonn S, Lawn JE. Saving the lives of South Africa's mothers, babies, and children: can the health system deliver? Lancet. 2009 Sep 5;374(9692):835-46. Epub 2009 Aug 24. Review. PubMed PMID: 19709729.

[18] Lawn J, Kerber K, editors. Opportunities for Africa's newborns. Cape Town: The Partnership for Maternal, Newborn \& Child Health; 2006. 246 p.

[19] Walley JD, McDonald M. Integration of mother and child health services in Ethiopia. Trop Doct. 1991 Jan;21(1):32-5. PubMed PMID: 1998221.

[20] Bhuyan KK. Health promotion through self-care and community participation: elements of a proposed programme in the developing countries. BMC Public Health. 2004 Apr 16;4:11. Review. PubMed PMID: 15086956; PubMed Central PMCID: PMC419355.

[21] World Health Organization, Department of Child and Adolescent Health Development. Highlights: Child and adolescent health and development progress report 2000-2001. Geneva: WHO Press; 2002. 86 p.

[22] Wolfe, MW. Mother and Child: A multi-determinant model for maternal and infant health outcomes in urban, low-income communities and the effectiveness of prenatal care and other interventions. J Public \& Int Aff [Internet]. 2006 Spring [cited 2011 Mar 18];179(169). Available from: http://ssrn.com/abstract=979683.

[23] Kumar V, Datta N. Home-based mothers' health records. World Health Forum. 1988;9(1):107-10. PubMed PMID: 3254189.

[24] Shah PM, Selwyn BJ, Shah K, Kumar V. Evaluation of the home-based maternal record: a WHO collaborative study. Bull World Health Organ. 1993;71(5):535-48. PubMed PMID: 8261557; PubMed Central PMCID: PMC2393478.

[25] World Health Organization, Child Health and Development Maternal and Child Health and Family Planning. Physical growth and psychosocial development of children: Monitoring and interventions, Protocol III, design and evaluation of the child's home-based record. Geneva: World Health Organization; 1992. 40 p.

[26] World Health Organization. Home-based maternal records: guidelines for development, adaptation and evaluation. Geneva: World Health Organization; 1994. 85p. 
Patient-Held Maternal and/or Child Health Records: Meeting the Information Needs of Patients and Healthcare Providers in Developing Countries?

[27] AIDSTAR-One. Mother-Infant Health Cards [Internet]. Washington, DC: USAID [updated unknown; cited 2011 Mar 18]. Available from: http://www.aidstarone.com/focus_areas/pmtct/resources/mother_to_child_health_cards.

[28] Kenya in bid to stem child deaths. Daily Nation [Internet]. 2010 Mar 1 [cited 2011 Mar 18]. Available from: http://www.nation.co.ke/News/-/1056/871194/-/vr4yoy/$1 \& \mathrm{ct}=$ ga\&cd=L7ZSXv9HOIo\&usg=AFQjCNHLLmjMC1qDckcJ8QBNIK0VrOqkQQ

[29] Wambui S. Kenya mover to curb child mortality. Capital News [Internet]. 2010 Apr 23 [cited 2011 Mar 18]. Available from: http://www.capitalfm.co.ke/news/Kenyanews/Kenyamoves-to-curb-child-mortality-8222.html

[30] Maisori CT. Launch of Mother-Child Booklet 2010 Apr 29 [cited 2011 Mar 18]. In: GIZ Health Sector Programme in Kenya: Home [Internet]. Nairobi: GIZ Health Sector Programme in Kenya c2006-2011. [about 1 post]. Available from: http://www.gtzkenyahealth.com/blog3/?p=3859.

[31] Maternal \& Child Health Booklet [Internet]. Ministry of Health Government of Kenya; [cited 2011 Mar 18]. Available from: http://www.aidskenya.org/public_site/webroot/cache/article/file/maternal_child.pdf.

[32] Schlosser R, Wendt O, Bhavnani S, Nail-Chiwetalu B. Use of information-seeking strategies for developing systematic reviews and engaging in evidence-based practice: the application of traditional and comprehensive Pearl Growing. A review. Int J Lang \& Commun Disord. 2006 Sep/Oct;41(5):567-82.

[33] Booth, A. Unpacking your literature search toolbox: on search styles and tactics. Health Info Libr J. 2008 Dec;25(4):313-7. PubMed PMID:19076679.

[34] Fairer-Wessels FA. Basic community information needs of urban black women in Mamelodi, Pretoria, South Africa. S Afr J Libr Inf Sci. 1990;58(4):359-69.

[35] Ngimwa P, Ocholla DN, Ojiambo J. Media accessibility and utilization by Kenyan rural women. Int Inf \& Lib Rev. 1997 Mar;29(1):45-66.

[36] Lugina HI, Christensson K, Massawe S, Nystrom L, Lindmark G. Change in maternal concerns during the 6 weeks postpartum period: a study of primaparous mothers in Dar es Salaam, Tanzania. J Midwifery Womens Health. 2001 Jul-Aug;46(4):248-57. PubMed PMID: 11603640.

[37] Lugina HI, Nyström L, Christensson K, Lindmark G. Assessing mothers' concerns in the postpartum period: methodological issues. J Adv Nurs. 2004 Nov;48(3):279-90. PubMed PMID: 15488042.

[38] Mooko NP. The information behaviors of rural women in Botswana. Lib \& Inf Sci Res. 2005 Winter;27(1):115-27.

[39] Mooko, NP. A study of the family information needs and information seeking behaviors of rural women in Botswana [dissertation]. [Pittsburgh]: University of Pittsburgh; 2002. 217 p.

[40] Ertem IO, Atay G, Dogan DG, Bayhan A, Bingoler BE, Gok CG, Ozbas S, Haznedaroglu D, Isikli S. Mothers' knowledge of young child development in a developing country. Child Care Health Dev. 2007 Nov;33(6):728-37. PubMed PMID: 17944782. 
Patient-Held Maternal and/or Child Health Records: Meeting the Information Needs of Patients and Healthcare Providers in Developing Countries?

[41] Bankole A, Biddlecom A, Guiella G, Singh S, Zulu E. Sexual behavior, knowledge and information sources of very young adolescents in four sub-Saharan African countries. Afr J Reprod Health. 2007 Dec;11(3):28-43. PubMed PMID: 18458739; PubMed Central PMCID: PMC2367131.

[42] Green JM, Coupland VA, Kitzinger JV. Expectations, experiences, and psychological outcomes of childbirth: a prospective study of 825 women. Birth. 1990 Mar;17(1):15-24. PubMed PMID: 2346576.

[43] Baker LM, Wilson FL, Nordstrom CK, Legwand C. Mothers' knowledge and information needs relating to childhood immunizations. Issues Compr Pediatr Nurs. 2007 Jan-Jun;30(12):39-53. PubMed PMID: 17613141.

[44] Smith SK, Dixon A, Trevena L, Nutbeam D, McCaffery KJ. Exploring patient involvement in healthcare decision making across different education and functional health literacy groups. Soc Sci Med. 2009 Dec;69(12):1805-12. Epub 2009 Oct 19. PubMed PMID: 19846245.

[45] Shieh C, Mays R, McDaniel A, Yu J. Health literacy and its association with the use of information sources and with barriers to information seeking in clinic-based pregnant women. Health Care Women Int. 2009 Nov;30(11):971-88. PubMed PMID: 19809901.

[46] Shieh C, McDaniel A, Ke I. Information-seeking and its predictors in low-income pregnant women. J Midwifery Womens Health. 2009 Sep-Oct;54(5):364-72. PubMed PMID: 19720337.

[47] Shieh C, Broome ME, Stump TE. Factors associated with health information-seeking in low-income pregnant women. Women Health. 2010 Jul;50(5):426-42. PubMed PMID: 20853218.

[48] Hartfield VJ. An ante-natal record card for use in developing countries. Trop Doct. 1973 Oct;3(4):171-3. PubMed PMID: 4745121.

[49] Dissevelt AG, Kornman JJ, Vogel LC. An antenatal record for identification of high risk cases by axliliary midwives at rural health centres. Trop Geogr Med. 1976 Sep;28(3):2515. PubMed PMID: 1006796.

[50] Sims P. Ante-natal card for developing countries. Trop Doct. 1978 Jul;8(3):137-40. PubMed PMID: 675805.

[51] Shah KP, Shah PM. The mother's card: a simplified aid for primary health workers. WHO Chron. 1981 Feb;35(2):51-3. PubMed PMID: 7222640.

[52] Chabot HT, Eggens KH. Antenatal card for illiterate traditional birth attendants. Trop Doct. 1986 Apr;16(2):75-8. PubMed PMID: 3765084.

[53] Poulton EM. Organisation of $\mathrm{MCH}$ services in developing regions. 3: records. J Trop Pediatr Afr Child Health. 1966 Dec;12(3):80-3. PubMed PMID: 5299730.

[54] Essex BJ, Everett VJ. Use of an action-orientated record for antenatal screening. Trop Doct. 1977 Jul;7(3):134-8. PubMed PMID: 302047. 
Patient-Held Maternal and/or Child Health Records: Meeting the Information Needs of Patients and Healthcare Providers in Developing Countries?

[55] Alisjahbana A, Widjaya J, Sukadi A. A method of reporting and identifying high risk infants for traditional birth attendants. J Trop Pediatr. 1984 Feb;30(1):17-22. PubMed PMID: 6737538 .

[56] Kennedy I, Ritter H. Antenatal records: do they help us? A new record for watching fetal growth. Trop Doct. 1984 Jul;14(3):130-2. PubMed PMID: 6464177.

[57] Moidu K, Singh AK, Boström K, Chowdhury S, Trell E, Wigertz O, Kjessler B. Towards an essential data set: applicability in the domain of maternal health services. Methods Inf Med. 1992 Sep;31(3):182-92. PubMed PMID: 1406332.

[58] Phelan ST. The prenatal medical record: purpose, organization and the debate of print versus electronic. Obstet Gynecol Clin North Am. 2008 Sep;35(3):355-68, vii. Review. PubMed PMID: 18760224.

[59] Nakamura Y. Maternal and Child Health Handbook in Japan. Jpn Med Assoc J [Internet]. 2010 [cited 2011 Mar 18];53(4):259-65. Available from: http://www.med.or.jp/english/journal/pdf/2010_04/259_265.pdf.

[60] Kusumayati A, Nakamura Y. Increased utilization of maternal health services by mothers using the Maternal and Child Health Handbook in Indonesia. Kokusai Hoken Iryo (J Int Health) [Internet]. 2007 [cited 2011 Mar 18];22(3):143-51. Available from: http://www.jstage.jst.go.jp/article/jaih/22/3/22_143/_article.

[61] Harrison D, Heese HD, Harker H, Mann MD. An assessment of the 'road-to-health' card based on perceptions of clinic staff and mothers. S Afr Med J. 1998 Nov;88(11):1424-8. PubMed PMID: 9861949.

[62] Mahomed K, Mason E, Warndorf T. Home-based mother's record: operational feasibility, understanding and usage in a rural community in Zimbabwe. Trop Doct. 2000 Jul;30(3):155-9. PubMed PMID: 10902474.

[63] Tarwa C, De Villiers FPR. The use of the Road to Health Card in monitoring child health. S Afr Fam Pract. 2007 Jan-Feb [cited 2011 Mar 18];49(1):15-15d. Available from: http://www.safpj.co.za/index.php/safpj/article/viewFile/486/637

[64] Draper J, Field S, Thomas H, Hare MJ. Should women carry their antenatal records? Br Med J (Clin Res Ed). 1986 Mar 1;292(6520):603. PubMed PMID: 3081189; PubMed Central PMCID: PMC1339577.

[65] Elbourne D, Richardson M, Chalmers I, Waterhouse I, Holt E. The Newbury Maternity Care Study: a randomized controlled trial to assess a policy of women holding their own obstetric records. Br J Obstet Gynaecol. 1987 Jul;94(7):612-9. PubMed PMID: 3304403.

[66] Lovell A, Zander LI, James CE, Foot S, Swan AV, Reynolds A. The St. Thomas's Hospital maternity case notes study: a randomised controlled trial to assess the effects of giving expectant mothers their own maternity case notes. Paediatr Perinat Epidemiol. 1987 Apr;1(1):57-66. PubMed PMID: 3506191.

[67] Saffin K, Macfarlane A. How well are parent held records kept and completed? Br J Gen Pract. 1991 Jun;41(347):249-51. PubMed PMID: 1931204; PubMed Central PMCID: PMC1371589. 
Patient-Held Maternal and/or Child Health Records: Meeting the Information Needs of Patients and Healthcare Providers in Developing Countries?

[68] Charles R. An evaluation of parent-held child health records. Health Visit. 1994 Aug;67(8):270-2. PubMed PMID: 7960831.

[69] Jeffs D, Nossar V, Bailey F, Smith W, Chey T. Retention and use of personal health records: a population-based study. J Paediatr Child Health. 1994 Jun;30(3):248-52. PubMed PMID: 8074911.

[70] Webster J, Forbes K, Foster S, Thomas I, Griffin A, Timms H. Sharing antenatal care: client satisfaction and use of the 'patient-held record'. Aust N Z J Obstet Gynaecol. 1996 Feb;36(1):11-4. PubMed PMID: 8775241.

[71] Homer CS, Davis GK, Everitt LS. The introduction of a woman-held record into a hospital antenatal clinic: the bring your own records study. Aust N Z J Obstet Gynaecol. 1999 Feb;39(1):54-7. PubMed PMID: 10099751.

[72] Phipps H. Carrying their own medical records: the perspective of pregnant women. Aust N Z J Obstet Gynaecol. 2001 Nov;41(4):398-401. PubMed PMID: 11787912.

[73] Usha Kiran TS, Jayawickrama NS. Hand-held maternity records: are they an added burden? J Eval Clin Pract. 2002 Aug;8(3):349-52. PubMed PMID: 12164982.

[74] Shaw E, Howard M, Chan D, Waters H, Kaczorowski J, Price D, Zazulak J. Access to webbased personalized antenatal health records for pregnant women: a randomized controlled trial. J Obstet Gynaecol Can. 2008 Jan;30(1):38-43. PubMed PMID: 18198066.

[75] Clendon J, Dignam D. Child health and development record book: tool for relationship building between nurse and mother. J Adv Nurs. 2010 May;66(5):968-77. Epub 2010 Mar 22. PubMed PMID: 20337798.

[76] Brown HC, Smith HJ. Giving women their own case notes to carry during pregnancy. Cochrane Database Syst Rev. 2004;(2):CD002856. Review. PubMed PMID: 15106181.

[77] Bjerkeli Grøvdal L, Grimsmo A, Ivar Lund Nilsen T. Parent-held child health records do not improve care: a randomized controlled trial in Norway. Scand J Prim Health Care. 2006 Sep;24(3):186-90. PubMed PMID: 16923629.

[78] Giglio R, Spears B, Rumpf D, Eddy N. Encouraging behavior changes by use of client-held health records. Med Care. 1978 Sep;16(9):757-64. PubMed PMID: 682710.

[79] Liaw ST, Radford AJ, Maddocks I. The impact of a computer generated patient held health record. Aust Fam Physician. 1998 Jan;27 Suppl 1:S39-43. PubMed PMID: 9503735.

[80] Jerdén L, Weinehall L. Does a patient-held health record give rise to lifestyle changes? A study in clinical practice. Fam Pract. 2004 Dec;21(6):651-3. Epub 2004 Oct 1. PubMed PMID: 15465882.

[81] Dickey LL. Promoting preventive care with patient-held minirecords: a review. Patient Educ Couns. 1993 Jan;20(1):37-47. Review. PubMed PMID: 8474946.

[82] Lecouturier J, Crack L, Mannix K, Hall RH, Bond S. Evaluation of a patient-held record for patients with cancer. Eur J Cancer Care (Engl). 2002 Jun;11(2):114-21. PubMed PMID: $\underline{12099947 .}$

[83] Williams JG, Cheung WY, Chetwynd N, Cohen DR, El-Sharkawi S, Finlay I, Lervy B, Longo M, Malinovszky K. Pragmatic randomised trial to evaluate the use of patient held 
Patient-Held Maternal and/or Child Health Records: Meeting the Information Needs of Patients and Healthcare Providers in Developing Countries?

records for the continuing care of patients with cancer. Qual Health Care. 2001 Sep;10(3):159-65. PubMed PMID: 11533423; PubMed Central PMCID: PMC1743428.

[84] Drury M, Yudkin P, Harcourt J, Fitzpatrick R, Jones L, Alcock C, Minton M. Patients with cancer holding their own records: a randomised controlled trial. Br J Gen Pract. 2000 Feb;50(451):105-10. PubMed PMID: 10750206; PubMed Central PMCID: PMC1313626.

[85] Cornbleet MA, Campbell P, Murray S, Stevenson M, Bond S; Joint Working Party of the Scottish Partnership Agency for Palliative and Cancer Care and National Council for Hospice and Specialist Palliative Care Services. Patient-held records in cancer and palliative care: a randomized, prospective trial. Palliat Med. 2002 May;16(3):205-12. PubMed PMID: 12046996.

[86] Lester H, Allan T, Wilson S, Jowett S, Roberts L. A cluster randomised controlled trial of patient-held medical records for people with schizophrenia receiving shared care. Br J Gen Pract. 2003 Mar;53(488):197-203.

[87] Gysels M, Richardson A, Higginson IJ. Does the patient-held record improve continuity and related outcomes in cancer care: a systematic review. Health Expect. 2007 Mar;10(1):75-91. Review. PubMed PMID: 17324196.

[88] Ko H, Turner T, Jones C, Hill C. Patient-held medical records for patients with chronic disease: a systematic review. Qual Saf Health Care. 2010 Oct;19(5):e41. Epub 2010 May 28. Review. PubMed PMID: 20511601.

[89] Kumar V, Walia I. Pictorial maternal and neonatal records for illiterate traditional birth attendants. Int J Gynaecol Obstet. 1981 Aug;19(4):281-4. PubMed PMID: 6172300.

[90] Watson DS. Use of "at risk" antenatal score card by aboriginal health workers in Arnhem Land. Trop Doct. 1984 Jul;14(3):133-5. PubMed PMID: 6464178.

[91] Abraham S, Joseph A. Evaluation of a home based antenatal card. J Trop Pediatr. 1985 Feb;31(1):39-42. PubMed PMID: 3981694.

[92] Abraham S, Joshi S, Kumar V, Patwary A, Pratinidhi A, Saxena VB, Maitra K, Singh KK, Saxena NC, Saxena BN. Indian experience of home based mothers card: ICMR task force study. Indian J Pediatr. 1991 Nov-Dec;58(6):795-804. PubMed PMID: 1818874.

[93] Daly AD, Nxumalo MP, Biellik RJ. Missed opportunities for vaccination in health facilities in Swaziland. S Afr Med J. 2003 Aug;93(8):606-10. PubMed PMID: 14531121.

[94] Corrigall J, Coetzee D, Cameron N. Is the Western Cape at risk of an outbreak of preventable childhood diseases? Lessons from an evaluation of routine immunisation coverage. S Afr Med J. 2008 Jan;98(1):41-5. PubMed PMID: 18270640.

[95] Osaki K, Hattori T, Kosen S, Singgih B. Investment in home-based maternal, newborn and child health records improves immunization coverage in Indonesia. Trans R Soc Trop Med Hyg. 2009 Aug;103(8):846-8. Epub 2009 Apr 16. PubMed PMID: 19375141.

[96] Mukanga DO, Kiguli S. Factors affecting the retention and use of child health cards in a slum community in Kampala, Uganda, 2005. Matern Child Health J. 2006 Nov;10(6):54552. PubMed PMID: 16850275. 
Patient-Held Maternal and/or Child Health Records: Meeting the Information Needs of Patients and Healthcare Providers in Developing Countries?

[97] Chabot HT, Rutten AM. Use of antenatal cards for literate health personnel and illiterate traditional birth attendants: an overview. Trop Doct. 1990 Jan;20(1):21-4. PubMed PMID: $\underline{2305476 .}$.

[98] Kumar R. Streamlined records benefit maternal and child health care. World Health Forum. 1993;14(3):305-7. PubMed PMID: 8397747.

[99] Goldman N, Pebley AR. Health cards, maternal reports and the measurement of immunization coverage: the example of Guatemala. Soc Sci Med. 1994 Apr;38(8):1075-89. PubMed PMID: 8042056.

[100]Nuwaha F, Kabwongyera E, Mulindwa G, Barenzi E. National immunisation days for polio eradication in Uganda: did immunisation cards increase coverage? East Afr Med J. 2000 Feb;77(2):66-70. PubMed PMID: 10774077.

[101] McElligott JT, Darden PM. Are patient-held vaccination records associated with improved vaccination coverage rates? Pediatrics. 2010 Mar;125(3):e467-72. Epub 2010 Feb 15. PubMed PMID: 20156897.

[102] MacFarlane A, Saffin K. Do general practitioners and health visitors like 'parent held' child health records? Br J Gen Pract. 1990 Mar;40(332):106-8. PubMed PMID: 2112011; PubMed Central PMCID: PMC1371075.

[103]Toohill J, Soong B, Meldrum M. Risk management considerations and the pregnancy handheld record. An audit of the return rate of the pregnancy handheld record. Women Birth. 2006 Dec;19(4):113-6. Epub 2006 Sep 22. PubMed PMID: 16996332.

[104] Wilkinson SA, Miller YD. Improving health behaviours during pregnancy: a new direction for the pregnancy handheld record. Aust N Z J Obstet Gynaecol. 2007 Dec;47(6):464-7. PubMed PMID: 17991110.

[105]Atkin PA, Finnegan TP, Ogle SJ, Shenfield GM. Are medication record cards useful? Med J Aust. 1995 Mar 20;162(6):300-1. PubMed PMID: 7715491.

[106]Dijkstra RF, Braspenning JC, Huijsmans Z, Akkermans RP, van Ballegooie E, ten Have P, Casparie T, Grol RP. Introduction of diabetes passports involving both patients and professionals to improve hospital outpatient diabetes care. Diabetes Res Clin Pract. 2005 May;68(2):126-34. Epub 2005 Jan 11. PubMed PMID: 15860240.

[107]Dale O, Hagen KB. Despite technical problems personal digital assistants outperform pen and paper when collecting patient diary data. J Clin Epidemiol. 2007 Jan;60(1):8-17. Epub 2006 Aug 30. Review. PubMed PMID: 17161749

[108] Thomas SM, Overhage JM, Warvel J, McDonald CJ. A comparison of a printed patient summary document with its electronic equivalent: early results. Proc AMIA Symp. 2001:701-5. PubMed PMID: 11825276; PubMed Central PMCID: PMC2243457.

[109]Blake H. Innovation in practice: mobile phone technology in patient care. Br J Community Nurs. 2008 Apr;13(4):160, 162-5. Review. PubMed PMID: 18595303.

[110]Walker I, Sigouin C, Sek J, Almonte T, Carruthers J, Chan A, Pai M, Heddle N. Comparing hand-held computers and paper diaries for haemophilia home therapy: a randomized trial. Haemophilia. 2004 Nov;10(6):698-704. PubMed PMID: 15569164. 
Patient-Held Maternal and/or Child Health Records: Meeting the Information Needs of Patients and Healthcare Providers in Developing Countries?

[111]Wu RC, Straus SE. Evidence for handheld electronic medical records in improving care: a systematic review. BMC Med Inform Decis Mak. 2006 Jun 20;6:26. Review. PubMed PMID: 16787539; PubMed Central PMCID: PMC1538581.

[112]Diero L, Rotich JK, Bii J, Mamlin BW, Einterz RM, Kalamai IZ, Tierney WM. A computer-based medical record system and personal digital assistants to assess and follow patients with respiratory tract infections visiting a rural Kenyan health centre. BMC Med Inform Decis Mak. 2006 Apr 10;6:21. PubMed PMID: 16606466; PubMed Central PMCID: PMC1482308

[113] Anantraman V, Mikkelsen T, Khilnani R, Kumar VS, Pentland A, Ohno-Machado L. Open source handheld-based EMR for paramedics working in rural areas. Proc AMIA Symp. 2002:12-6. PubMed PMID: 12463777; PubMed Central PMCID: PMC2244537.

[114]Bernabe-Ortiz A, Curioso WH, Gonzales MA, Evangelista W, Castagnetto JM, Carcamo CP, Hughes JP, Garcia PJ, Garnett GP, Holmes KK. Handheld computers for selfadministered sensitive data collection: a comparative study in Peru. BMC Med Inform Decis Mak. 2008 Mar 19;8:11. PubMed PMID: 18366687; PubMed Central PMCID: PMC2323371.

[115]Mukund Bahadur KC, Murray PJ. Cell phone short messaging service (SMS) for HIV/AIDS in South Africa: a literature review. Stud Health Technol Inform. 2010;160(Pt 1):530-4. Review. PubMed PMID: 20841743.

[116] Koskinen E, Salminen J. A customizable mobile tool for supporting health behavior interventions. Conf Proc IEEE Eng Med Biol Soc. 2007:5908-11. PubMed PMID: 18003358.

[117]Bielli E, Carminati F, La Capra S, Lina M, Brunelli C, Tamburini M. A Wireless Health Outcomes Monitoring System (WHOMS): development and field testing with cancer patients using mobile phones. BMC Med Inform Decis Mak. 2004 Jun 15;4:7. PubMed PMID: 15196308; PubMed Central PMCID: PMC441394.

[118]Kundu S, Mukherjee J, Majumdar AK, Majumdar B, Sekhar Ray S. Algorithms and heuristics for efficient medical information display in PDA. Comput Biol Med. 2007 Sep;37(9):1272-82. Epub 2007 Jan 12. PubMed PMID: 17222816.

[119] Overdyk FJ, Haynes GR, Arvanitis PJ. Patient-borne memory device facilitates "point of care" data access. MD Comput. 1999 May-Jun;16(3):60-3. PubMed PMID: 10439604.

[120]Blake H. Mobile phone technology in chronic disease management. Nurs Stand. 2008 Nov 26-Dec 2;23(12):43-6. Review. PubMed PMID: 19093357.

[121] Katz DL, Nordwall B. Novel interactive cell-phone technology for health enhancement. J Diabetes Sci Technol. 2008 Jan;2(1):147-53. PubMed PMID: 19885191; PubMed Central PMCID: PMC2769699.

[122] Pena V, Watson AJ, Kvedar JC, Grant RW. Mobile phone technology for children with type 1 and type 2 diabetes: a parent survey. J Diabetes Sci Technol. 2009 Nov 1;3(6):14819. PubMed PMID: 20144404; PubMed Central PMCID: PMC2787050.

[123]Inter-American Development Bank. Project profile: Mobile citizens - solutions at hand. Maternal health information: Getting connected for better maternal and child health 
Patient-Held Maternal and/or Child Health Records: Meeting the Information Needs of Patients and Healthcare Providers in Developing Countries?

[Internet]. [place unknown]: Inter-American Development Bank; c2009 [cited 2011 Apr 20]. Available from: http://www.mobilecitizen.bidinnovacion.org/en/projects.html.

[124]Martínez A, Villarroel V, Seoane J, del Pozo F. Analysis of information and communication needs in rural primary health care in developing countries. IEEE Trans Inf Technol Biomed. 2005 Mar;9(1):66-72. PubMed PMID: 15787009

[125]Patrick K, Griswold WG, Raab F, Intille SS. Health and the mobile phone. Am J Prev Med. 2008 Aug;35(2):177-81. Epub 2008 Jun 12. PubMed PMID: 18550322; PubMed Central PMCID: PMC2527290. 